\title{
MONASHUniversity
}

Business and Economics

Workplace and Corporate Law Research Group

Working Paper No. 18

July 2012

\section{THE EVOLUTION OF LABOUR LAW IN INDIA: AN OVERVIEW AND COMMENTARY ON REGULATORY OBJECTIVES AND DEVELOPMENT}

\author{
Richard Mitchell, Petra Mahy and Peter Gahan
}

The Workplace and Corporate Law Research Group (WCLRG) is a research concentration within the Department of Business Law \& Taxation, Faculty of Business \& Economics, at Monash University. It has been in operation since March 2008, having previously operated as the Corporate Law and Accountability Research Group (CLARG) since November 2005.

WCLRG invites the submission of papers for publication in its Working Paper Series. Submissions on workplace relations and employment law, labour market regulation, corporate governance, corporate social responsibility, and the intersections between labour law and corporate law are welcomed. For details, go to: http://www.buseco.monash.edu.au/blt/wclrg/working-papers.html 


\title{
THE EVOLUTION OF LABOUR LAW IN INDIA: AN OVERVIEW AND \\ COMMENTARY ON REGULATORY OBJECTIVES AND DEVELOPMENT
}

\author{
Richard Mitchell, Petra Mahy and Peter Gahan*
}

\begin{abstract}
Never before in human history have so few owed so much to so many...A handful of men in this country have trained the remaining 99.9 per cent - as strong, as talented, as intelligent in every way - to exist in perpetual servitude: a servitude so strong that you can put the key of his emancipation in a man's hands and he will throw it back at you with a curse. You'll have to come here and see it for yourself to believe it. Every day millions wake up at dawn - stand in dirty, crowded buses - get off at their masters' posh houses - and then clean the floors, wash the dishes, weed the garden, feed their children, press their feet - all for a pittance: Aravind Adiga, The White Tiger, Atlantic Books, London, 2009, pp. 175-176.
\end{abstract}

\section{Introduction}

In a recent account of the trends in the regulation of working conditions in Asia and the Pacific region it was suggested that there was a lack of in-depth historical research on the evolution of labour law in many developing countries. ${ }^{1}$ India, it seems, may well be a case in point. Although there is a great amount of written material on Indian labour law and associated topics, much of it is of a highly fragmented nature, comprised of very short articles and notes on the very wide range of matters covered in India's voluminous array of employment, social security and labour laws. ${ }^{2}$ There are also a number of conventional labour law texts and commentaries which are descriptive of the labour laws and institutions. ${ }^{3}$

\footnotetext{
* Petra Mahy and Richard Mitchell are in the Department of Business Law and Taxation at Monash University, Australia. Peter Gahan is in the Department of Management at The University of Melbourne, Australia. The authors wish to acknowledge the contribution by way of very detailed comments on an earlier version of this paper provided by Professor Debi Saini of the Management Development Institute, Gurgaon, India. All remaining errors in the paper are the responsibility of the authors.

${ }^{1}$ D. McCann, 'The Regulation of Working Conditions in Asia and the Pacific: Flexibility, Fragmentation and Worker's Rights' in S. Lee and F. Eyraud (eds.), Globalization, Flexibilization and Working Conditions in Asia and the Pacific, International Labour Office and Chandos Publishing, Geneva and Oxford, 2008, pp. 90-91.

2 See the relevant entries in the Index to Indian Legal Periodicals, Vols. 1-49, The Indian Law Institute, 19622011. The major 'relevant to labour' periodicals include The Economic and Political Weekly, Labour and Industrial Cases, The Labour Law Reporter, and the Manpower Journal. As we note below (see n. 6) The Indian Journal of Industrial Relations also contains scholarly contributions on labour law. As would be expected, labour law articles are sometimes included in more generalist Indian legal journals, including those published by Indian university law schools.

${ }^{3}$ Leading labour law texts include: G.M. Kothari and A.G. Kothari, A Study of Industrial Law, Vols. 1 and 2, N. M. Tripathi Private Limited, Bombay, $4^{\text {th }}$ edition, 1987; S. Malik, P. L. Malik's Industrial Law, Vols. 1 and
} 
But a search of English language sources on Indian labour law reveals little by way of what might be regarded as a unified historical account of its evolution covering both central and provincial sources, and its relation to its political, social and economic contexts. ${ }^{4}$ And, strangely for a country whose constitution guarantees certain labour rights and whose laws include upwards of 150 separate pieces of labour legislation arising from central and state government authorities, there is no specialist labour law journal ${ }^{5}$ promoting scholarly engagement in the field notwithstanding the law's obvious relevance in political and industrial terms. ${ }^{6}$

In this paper we are aiming to provide a broad overview of the development of labour law in India. Two notes of caution are due. First, the Indian system of labour laws is very extensive and dauntingly complex. Our descriptions of the laws (mainly legislation) are very general, and are intended only to sketch out the broad parameters of Indian government policy in the regulation of employment relationships and labour markets. Secondly, we are drawing basically from secondary sources, and attempting to put the development of the law into a broader socio-political context. In particular we intend to examine the evolution of Indian labour law from two perspectives. The first of these deals with the important time periods through which the law has progressed since the earliest regulation of the nineteenth century. The second deals with the quality, purpose and impact of Indian labour law. Here we are interested not merely in what we think Indian labour law sets out to do, but also particularly in the various uncertainties and ambiguities which seem to characterise the way in which Indian labour law has been perceived by scholars and experts over the course of its development. We conclude with a consideration of what particular aspects of the Indian political economy have meant for Indian labour law, and what this might mean for the study of labour law more generally.

2, Eastern Book Co., Lucknow, $23^{\text {rd }}$ ed., 2011; S.N. Mishra, Labour and Industrial Laws, Central Law Publications, Allahabad, $26^{\text {th }}$ edition, 2011.

${ }^{4}$ A useful recent addition to the literature is the ten volume Labour Regulation in India series, published by the Institute for Studies in Industrial Development under the general editorship of T.S. Papola (New Delhi, 2008).

${ }^{5}$ The contents of the Labour Law Journal of India, which has been in publication for more than sixty years, are almost entirely comprised of reported case decisions.

${ }^{6}$ According to at least one authority 'Labor relations in India is defined by law': V. DeSousa, 'Colonialism and Industrial Relations in India' in S. Kuruvilla and B. Mundell (eds.), Colonialism, Nationalism and the Institutionalization of Industrial Relations in the Third World, JAI Press, Stamford, 1999, at p. 65. However, of upwards of 1,400 articles published in the Indian Journal of Industrial Relations between 1965 and 2011, only about 25 were focussed on labour law per se. 


\section{The Evolution of Labour Law in India ${ }^{7}$}

Discussion of Indian labour law and industrial relations is often divided into discrete time periods, reflecting important stages in the evolution of the Indian state as well as stages of economic development and policy. ${ }^{8}$ Writing in 1955 , Ornati suggested three key periods in the evolution of Indian labour law to that point of time. ${ }^{9}$ The earliest regulation was largely designed as labour control, ${ }^{10}$ but this was eventually added to by a sequence of factory-type regulation, providing for some basic levels of protection, between the 1880s and the 1930s. This legislation essentially reflected an accommodation of sorts between the interests of British industry, seeking protection for its domestic enterprises against cheap foreign labour, and Indian social reformers intent on improving what were regarded as sub-human working conditions in Indian factories. ${ }^{11}$ In the view of some commentators, this early period of labour law reform was largely 'formal or unimportant' constituting only a 'minimum of interference with the working conditions of labour and the relationship between the employer and the worker'. ${ }^{12}$

A second period (1937-1947), Ornati suggests, was more creative, and began with the emergence of 'Provincial Autonomy' in the second half of the 1930s, the focus of the Indian Congress Party on worker's rights (including such matters as standards of living, trade union rights, the right to strike and so on), and the introduction of greater uniformity through the extension of workplace regulation. ${ }^{13}$ The third period in Ornati's analysis begins with the critical post-Independence legislation of the late 1940s and early 1950s.

\footnotetext{
${ }^{7}$ See generally, K. N. Vaid, State and Labour in India, Asian Publishing House, London, 1965, chs. 3 and 5 in particular; S. Mishra, Modern Labour Laws and Industrial Relations, Deep and Deep Publications, New Delhi, 1992, pp. 13-18.

${ }^{8}$ See, for example, Van D. Kennedy, 'The Sources and Evolution of Indian Labour Relations Policy' (1965) 1 Indian Journal of Industrial Relations 15; D. Bhattacherjee and P. Ackers, 'Introduction: Employment Relations in India - Old Narratives and New Perspectives' (2010) 41 Industrial Relations Journal 104; J. J. Thomas, 'An Uneasy Coexistence: The New and the Old in Indian Industry and Services' in A.P. D'Costa (ed.) A New India: Critical Reflections in the Long Twentieth Century, Anthem Press, London and New York, 2010.

${ }^{9}$ O. Ornati, Jobs and Workers in India, Institute of International Industrial and Labor Relations, Cornell University, Ithaca NY, 1955, at pp. 81-95.

${ }^{10}$ For example, The Workmen's Breach of Contract Act 1859; The Employers and Workmen's Act 1860; and The Penal Code 1860.

${ }^{11}$ C. Candland, Labor, Democratization and Development in India and Pakistan, Routledge, London, 2007, pp. 18-20; DeSousa, above n.6, pp. 65-74.

${ }^{12}$ V. K. R. Menon, 'The Influence of International Labour Conventions on Indian Labour Legislation' (1956) 73 International Labour Review 551, at p. 555. Ornati himself suggests that the earlier period reforms were 'conservative and narrow' when contrasted with the labour law developments of later periods: see above n. 9, at p. 89.

${ }^{13}$ See Ornati, above n. 9, at pp. 89-91.
} 
Ornati's analysis would suggest that there was nothing very eventful about early Indian labour law, but others have argued that there was important progress made in labour legislation in the immediate post-World War One period, pointing specifically to the influence of several International Labour Organisation (ILO) conventions and the Royal Commission on Labour in the 1920 s as major advances. ${ }^{14}$

For the purposes of present discussion we propose to examine the evolution of labour law in India, and the regulatory policy associated with it, across six main periods. ${ }^{15}$

\section{Pre-1920s}

In the very early stages of British colonial control, there was little attention paid to the legal organisation of work by the authorities. Labour organisation and the production process remained, apart from a few exceptions, a matter of family, land and cultural regulation. ${ }^{16}$ The earliest British regulations related to workers in the government service, including the military, and 'forced labour' for the performance of public works. ${ }^{17}$

However, as we have noted briefly above, from the 1880s onwards there was a succession of legislative interventions by the colonial government, mainly in relation to the employment of women and children, and concerning hours of work, in factories and mines. ${ }^{18}$ Much of this

\footnotetext{
${ }^{14}$ See A. Amjad, Labour Legislation and Trade Unions in India and Pakistan, Oxford University Press, Oxford, 2001, at p. 36; Menon, above n. 12, at p. 555; R. K. Das, 'Labour Legislation in Indian States' (1938) 38 International Labour Review 794; K. Sankaran, 'Labour Law in South Asia: The Need for an Inclusive Approach' in T. Tekle (ed.), Labour Law and Worker Protection in Developing Countries, Hart/International Labour Office, Oxford and Geneva, 2010, at p. 227.

${ }^{15}$ A different scenario in terms of periodisation in the evolution of Indian labour policy is presented by Shyam Sundar: see K. R. S. Sundar, 'State in Industrial Relations System in India: From Corporatist to Neo-Liberal?' (2005) 48 Indian Journal of Labour Economics 917. See also Mishra, above n.7, at pp. 13-18; and E. Hill, 'The Indian Industrial Relations System: Struggling to Address the Dynamics of a Globalizing Economy' (2009) 51 Journal of Industrial Relations 395.

${ }^{16}$ These continue to be highly significant factors in the organisation and regulation of labour. For a detailed study of one Indian region see: J. G. Scoville, M. Toha and S. Triparthi, 'Ethnicity, Caste, Religion and Occupational Structure in Traditional Activities: A Preliminary View from North India' in J. G. Scoville (ed.), Status Influences in Third World Labor Markets, Walter de Gruyter, Berlin, 1991. See also, S. Thorat and K. S. Newman (eds.), Blocked by Caste: Economic Discrimination in Modern India, Oxford University Press, New Delhi, 2010; B. Harriss-White and N. Gooptu,' Mapping India's World of Unorganized Labour' (2001) 37 Socialist Register 89; M. B. Das and P.V. Dutta, 'Does Caste Matter for Wages in the Indian Labour Market?' Social Development Unit, World Bank, 2007.

${ }^{17}$ For a discussion of the early origins of labour law in India see, M. R. Anderson, 'Work Construed: Ideological Origins of Labour Law in British India to 1918' in P. Robb (ed.), Dalit Movements and the Meaning of Labour in India, Oxford University Press, Delhi, 1993. See also P. Robb, Peasants, Political Economy, and Law, Oxford University Press, New Delhi, 2007, ch. 8.

${ }^{18}$ These include the Factories Acts of 1881, 1891 and 1911: see DeSousa, above n. 6, at pp. 68-74. Legislation in the mining industry commenced with the Indian Mines Act 1901.
} 
legislation was the result of various government-initiated enquiries. ${ }^{19}$ However, the legislation made only very slight inroads into working practices in these industries, and was of limited impact insofar as it applied only selectively. ${ }^{20}$ Regulation in the plantation sector was focussed principally upon matters relating to labour supply and the problems of the indentured labour system. ${ }^{21}$

\section{Post-World War One and the 1920s}

As we noted, there is some disagreement about the importance of this period. ${ }^{22}$ Several factors had combined to alter the industrial and political landscape, including the emergence of a strong nationalist movement, the rapid development of trade unions (most importantly the formation of the All India Trade Union Congress in 1920), and the emergence of Communist influence in the labour movement following the successful Bolshevik revolution in Russia in $1917 .^{23}$ At the same time the newly created ILO began to have an influence on labour policy in India. ${ }^{24}$

Much of the legislation of this period was a continuation of the 'factory'-style regulation of the pre-war period, dealing with hours of work, rest periods, female and child protections, health and safety and so on. Typical protective legislation of the period includes the Factories Act 1922, the Mines Act 1922, and the Workmen's Compensation Act 1923, much of it responding to the ratification of various relevant ILO conventions by the colonial Indian government. $^{25}$

However, even if this body of legislation is correctly characterised as 'unimportant" ${ }^{26}$ two further enactments in this period point to what has been described as the emergence of a more modern approach to the regulation of industrial relations: the Trade Unions Act 1926 and the

\footnotetext{
${ }^{19}$ These included the Labour Commission set up by the Governor of Bombay in 1875, the Bombay Factory Commission of 1884, the Government of India Factory Commission of 1890, the Textile Factory Committee 1906 and the Factory Labour Commission of 1907. See generally R. K. Das, 'Labour Legislation in India' (1930) 22 International Labour Review 599.

${ }^{20}$ The Factories Act of 1881, for example, only applied to premises using electrical power with 100 or more employees. The Factories Act of 1891 applied to premises with 50 or more employees.

${ }^{21}$ See generally Das, above n. 19. Early legislation addressing problems in the plantation sector includes the Assam Labour and Emigration Act of 1901, and the Assam Labour and Immigration (Amendment) Act of 1915.

${ }^{22}$ See above n. 12 and associated text.

${ }^{23}$ See Amjad, above n. 14, at pp. 33-38; Candland, above n. 11, at pp.18-19.

${ }^{24}$ See in particular Menon, above n. 12.

${ }^{25}$ See Amjad, above n. 14, pp. 33-47; DeSousa, above n.6, at pp. 79-81. The Workmen's Compensation Act was renamed the Employee's Compensation Act in 2010.

${ }^{26}$ See above n. 12 , and associated text.
} 
Trade Disputes Act 1929. ${ }^{27}$ The regulatory framework set down in these two provisions continues formally to underpin the collective labour law system of present day India.

The Trade Unions Act 1926 provided for the registration of trade unions (though registration was not made compulsory), gave unions a legal status, and extended some protections against civil and criminal liability in the course of industrial disputes. The Act was limited in certain respects (for example unregistered unions were excluded from the Act's protections), and the legislation provided no support for a collective bargaining system as such, insofar as there was no obligation upon employers to bargain with unions (even registered unions) in the course of an industrial dispute, nor, in the case of such bargaining, was there any legal obligation to bargain in good faith. The Trade Disputes Act 1929 placed severe limitations upon the right to strike, and provided for the compulsory reference of industrial disputes to a conciliation board or a court of enquiry. The outcomes of the reference, however, were not binding upon the parties.

Both pieces of legislation were strongly criticised by sections of the trade union movement, including the All India Trade Union Congress. ${ }^{28}$

\section{The 1930s}

In the context of world economic depression and the associated rise in unemployment, there was also in this period continued agitation for Indian independence in which the All India Trade Union Congress was playing a major role. ${ }^{29}$ Mass dismissals were accompanied by a renewed wave of strikes, especially as the economic depression took hold through 1928 and 1929. Against this background, the British government established the Royal Commission on Labour in India on the 4th July 1929. The Commission was effectively boycotted by the Indian labour movement, the All India Trade Union Congress pointing to the British Imperialist government's 'open and brutal attack upon the trade union movement by means of repressive legislation...' and its lack of 'bona fides' in establishing the Commission. ${ }^{30}$

\footnotetext{
${ }^{27}$ See Amjad, above n. 14, at ch. 4.

${ }^{28}$ Amjad, above n. 14, at pp. 36-39.

${ }^{29}$ See Amjad, above 14, at pp. 36-40. The British colonial government favoured the less nationalistic Indian Federation of Labour: see S. K. Sen, Working Class Movements in India, 1885-1975, OUP, New Delhi, 1994.

${ }^{30}$ See Amjad, above n. 14, at p. 46.
} 
The Commission handed down its Report ${ }^{31}$ in 1931, still a period of continued job cuts, wage reductions, and ongoing industrial unrest and strike action. But during the 1930s, two major factors began to put some further shape on Indian labour law. First, many of the outcomes of the Report of the Royal Commission made their way into a string of new labour legislation between 1933 and 1939. Menon estimates that of 24 pieces of labour legislation introduced by central and provincial governments between 1932 and 1937, 19 arose from the Royal Commission's recommendations. ${ }^{32}$ Virtually all of this new law was in the nature of protective factory and mines regulation to do with wages, hours of work, and compensation of one sort or another, similar to earlier periods. One exception was the Payment of Wages Act 1936, which empowered the employer to deduct wages of employees absent from work in concert, and without reasonable cause. A further example was the Trade Disputes (Amendment) Act 1938, which authorised provincial governments to appoint conciliation officers to assist in the settlement of disputes.

Secondly, and potentially more important, were the developments which followed from the Government of India Act 1935. The heightened profile given to provincial autonomy ${ }^{33}$ made possible under these new constitutional arrangements gave rise to popular expectation that more 'labour'- or 'union'-friendly policies would emerge at the provincial government level, ${ }^{34}$ and this in turn gave rise to further concentrated periods of extensive strike action. ${ }^{35}$

Even prior to the 1935 Act, several provincial governments had begun to experiment with labour law, much of it an important contribution to the development of better working

\footnotetext{
${ }^{31}$ Report of the Royal Commission on Labour in India, HMSO, London, Cmnd. 3883, 1931.

${ }^{32}$ See Menon, above n. 12, at p. 557

${ }^{33}$ The Royal Commission on Labour had 'recommended that legislative authority should remain with the central Government, though the states could also be given jurisdiction provided that no legislation was undertaken by the states without the previous concurrence of the central government and that such legislation did not impair or infringe the central Government's legislation': Menon, above n. 12, at p.556. As a matter of constitutional law, legislative power over labour and employment relations had been largely shared concurrently by both Central and State governments since 1919, and hence the Royal Commission was merely recommending the continuance of existing arrangements: see Menon, above n. 12, at pp. 552-554. This legal division of power was also continued in the Constitution of India which came into effect in 1950, following the securing of Indian independence from Britain in 1947. Under such legal arrangements Central and State governments have continued to legislate for labour relations. However, there has been ongoing debate over the years concerning the problems of co-ordination and uniformity of labour laws due to the overlap of powers: see Sir A. C. Chatterjee, 'Federalism and Labour Legislation in India' (1944) 49 International Labour Review 415; and, Das, above n. 19 at p. 621 emphasising lack of uniformity and other problems, and G. B. Pai, Labour Law in India, Butterworth, New Delhi, 2001, emphasising the capacity in these shared arrangements for flexibility in labour market regulation. This issue is pursued further in Section 3 of the paper: see below nn. 110-119 and associated discussion.

${ }_{35}^{34}$ Amjad, above n. 14, at pp. 49-50.

${ }^{35}$ Ibid.
} 
conditions in workplaces. ${ }^{36}$ Not all of this, however, was particularly directed to creating a more favourable environment for combined labour activity. One important instance was the introduction of the Trade Disputes (Conciliation) Act 1934 by the provincial government of Bombay. ${ }^{37}$ Whilst novel insofar as it was designed to effect changes to collective labour relations (by providing for the appointment of a Labour Officer to represent the interests and grievances of workers in the cotton mills), the 1934 Act seems to have been aimed mainly at heading off communist influence among the labour movement following many years of decline in the Bombay-based textile industries and a major strike earlier in that year. ${ }^{38}$

However, more adventurous legislation followed after the election of more popular provincial governments in the wake of the Government of India Act 1935. The introduction of the Industrial Disputes Act 1938 by the Bombay provincial government, for example, among other things made some move in towards the imposition of a legal obligation on the part of employers to recognise trade unions. ${ }^{39}$ Again it is necessary to note, however, that these were largely limited measures which were not greeted with general approval by the Indian trade union movement. The All India Trade Union Congress described the 1938 Bombay Bill as 'uncalled for, reactionary, prejudicial and harmful to the interest of the workers [and] "calculated to create slave unions". 40

In general it appears that the expectations created in the popular election of provincial governments remained largely unfulfilled.

\section{World War Two and the Pre-Independence Period}

Regulation in the World War Two period appears against the background of considerable industrial unrest and strike action against the conditions and affects of the war itself. These circumstances brought into being several pieces of legislation (at Central and State level) designed to secure labour co-operation in support of the war effort. This legislation included passage in 1941 of s. 49A of the Bombay Industrial Disputes Act, granting power to the Bombay government to refer industrial disputes to compulsory arbitration by an Industrial

\footnotetext{
${ }^{36}$ See Das, above n. 14.

${ }^{37}$ Similar style legislation on industrial disputes, strikes and so on was also introduced in Indore, Cochin and other Indian States during the 1930s: see Das, above n. 14, at p. 816-817.

${ }^{38}$ See Amjad, above n. 14, at p. 49; D. Kooiman, 'Labour Legislation and Working Class Movement: Case of Bombay Labour Office, 1934-37' (1981) 16 Economic and Political Weekly 1807; M. D. Morris, 'Labor Discipline, Trade Unions, and the State in India' (1955) 63 Journal of Political Economy 293.

${ }^{39}$ See Amjad, above n. 14, at pp. 50-52.

${ }^{40}$ Amjad, above n. 14, at p. 52.
} 
Court, and banning all strikes and lockouts prior to arbitration. Much of this restrictive legislation in the Bombay province was continued after the war ended in the form of the Bombay Industrial Relations Act $1946 .^{41}$ Other relevant legislation included the Central government's Essential Services Act 1941, and the Defence of India Rules (Rule 81-A, introduced in 1942, and Rule 56-A, introduced in 1943). Each of these sets of provisions ${ }^{42}$ laid down severe restrictions against strikes, and other forms of industrial action, in the course of industrial disputes, including industrial action on the part of employers in some cases. General and political strikes were also targeted. ${ }^{43}$ The provisions of Rule $81-\mathrm{A}$ in particular were continued after the war as part of the Industrial Disputes Act 1947, and, as is noted in subsequent sections of this paper, have remained a core part of the legislation governing industrial disputes and bargaining since that time.

To greater or lesser extent, the Trade Disputes Act 1929, its successor the Trade Disputes Act 1947, and earlier provisions such as the Bombay Act of 1934, were essentially designed to enable government agencies to investigate industrial disputes over relevant terms and conditions of employment, and to settle them in appropriate cases. ${ }^{44}$ But generally the terms of this legislation were historically directed more towards the control of labour than towards the settlement issue. Certainly there was little or nothing in these various provisions which facilitated the development of collective bargaining in a British- or American-style model. While strikes and lockouts were strictly controlled, the state, at both Central and State levels, exercised strong controls over the circumstances in which disputes might be referred to adjudication, the industries to which the legislation applied, and which unions might be permitted to notify such disputes. ${ }^{45}$

The overall impact of this was, then, one of limitation and exclusion. The Industrial Disputes Act 1947, for example, applied (and applies) generally to 'workmen' in 'industries'. 'Workmen' excluded various categories of workers engaged in particular occupations, or in managerial and administrative capacities, and so on. ${ }^{46}$ Whereas the term 'industry' has now

\footnotetext{
${ }^{41}$ Amjad, above n. 14, p. 55.

${ }^{42}$ For brief accounts see Amjad, above n. 14, at pp. 54-57.

${ }^{43}$ In India, many forms of industrial action are unlawful, and much industrial action is correspondingly unlawful in practice: see generally, C.K. Johri, 'India' in R. Blanpain (ed.) International Encyclopaedia for Labour Law and Industrial Relations, Kluwer Law International, Alphen aan den Rijn, Netherlands, Supplement 262, December 2002, at paras. 626-652.

${ }^{44}$ See the discussion in Section 3 of the paper around nn. 203-217.

${ }^{45}$ Amjad, above n. 14, at pp. 58-61.

${ }^{46}$ See for discussion, B. R. Sharma, 'Managerial Employees and Labour Legislation' (1992) 28 Indian Journal of Industrial Relations 1.
} 
been interpreted quite broadly, many types of employment, including workers in government departments and services, and domestic and agricultural workers are still excluded. Similarly the Trade Unions Act 1926 also contained important limitations on its coverage. ${ }^{47}$ It has been said of the system set up under the Industrial Disputes Act 1947 that 'the freedom of industrial action on the part of workers [is] more illusory than real' and that the 'provisions of the law [operate] to restrict the options available to the side represented by the workers' ${ }^{48}$ What collective bargaining there was, developed without state support and, not surprisingly, evolved almost entirely in the formal (or organised) sectors of the economy. ${ }^{49}$ These are largely confined to the public and large corporate sectors and constitute about 3 per cent or less of the workforce in each case. ${ }^{50}$

Most scholars have noted that the path taken in the evolution of labour law in India in the post-1945 period basically followed the pattern established earlier in the restrictive policies of the colonial government and in particular the legislation of the war years. ${ }^{51}$ Only in a few States were there exceptions made to the overall discretionary power of government to refer or not to refer disputes for adjudication, and in only a few States did laws emerge which created some sort of obligation upon employers to recognise trade unions. One such provision was the Bombay Industrial Relations Act 1946 which, building upon the earlier (and much criticised) attempts in the Bombay Industrial Disputes Act 1938, distinguished several types of unions, and extended to some of those unions the right to represent workers in particular industries and areas. ${ }^{52}$

\footnotetext{
${ }^{47}$ See generally, Johri, above n. 43, at paras. 125-152.

${ }^{48}$ Amjad, above n. 14, pp. 60 and 61.

${ }^{49}$ See T. Roy, Rethinking Economic Change in India, Routledge, London, 2005, at p. 179. Although India has never ratified the key ILO Conventions pertaining to Freedom of Association and Collective Bargaining, it has been pointed out that as a member of the organisation it has a general responsibility to support these rights from an ethical standpoint: see R. Gopalakrishnan and L. Tortell, 'Access to Justice, Trade Union Rights and the Indian Industrial Disputes Act, 1947' (2006) 22 International Journal of Comparative Labour Law and Industrial Relations 529, at pp. 542-543.

${ }^{50} \mathrm{We}$ are dealing with this question very generally here. The issue of what constitutes the 'organised', the 'semi-organised' and the 'unorganised' sectors of the Indian economy, and the relationship of these concepts with the idea of the 'informal' economy, is very complicated and quite unclear. Not surprisingly this has significant implications for how one characterises Indian labour law as a whole: see Sankaran, above n. 14, at pp. 230-231; Johri, above n. 43, at paras. 245-248, and paras. 654-682. The issue is pursued further in Section 3 of the paper: see nn. 183-194 and associated discussion.

${ }^{51}$ See, for example, Sundar, above n. 15, at p. 920; Gopalakrishnan and Tortell, above n. 49, at p. 537.

${ }^{52}$ See K. R. Shyam Sundar, Impact of Labour Regulations on Industrial Development and Employment: A Study of Maharashtra, Institute for Studies in Industrial Development, New Delhi, 2008, pp. 66-68; Johri, above n. 43, at paras. 551-554. There are similar laws in other Indian States: for example, the Indian Trade Unions (Madhya Pradesh Amendment) Act 1960.
} 
At the same time, however, there was a continued strengthening of the protective regulation applying to individual worker's rights during this period. One example is the Industrial Employment (Standing Orders) Act 1946 which required employers to provide their employees with clear terms and conditions of employment according to the items set down in a Schedule to the Act and certified by the relevant authority. Other major statutes of this period included the Factories Act 1948 and the Minimum Wage Act 1948. Much of this body of regulation, as we have noted also in the case of the Industrial Disputes Act 1947, was (and remains) limited in its application because it was applied only selectively to certain kinds of business establishments, and, in respect of some provisions, only to businesses of a certain size as determined by the number of employees. This is a common theme in Indian labour law, with obvious implications for the legitimacy of the labour law system as a whole. ${ }^{53}$

\section{Post-Independence, 1948 Onwards}

In the immediate post-war period it was agreed that the Indian Central government would be primarily responsible for labour legislation, and the promotion of labour's interests, reflecting a five-year plan of development 'dealing with all phases of the worker's life, of housing, welfare, work, better working conditions, and fair wages' ${ }^{54}$ Many of these social values were articulated in the Constitution of India 1950, particularly its commitment to economic, political and social justice in the Preamble, and its general egalitarian conception of national development. ${ }^{55}$

Consistent with this socio/political outlook, we have noted the introduction of a raft of protective legislation in the form of the Factories Act 1948, and the Minimum Wages Act 1948. Important also to note are the Dock Workers (Regulation of Employment) Act 1948, which among other things sought to 'decasualise' dock labour, the Employees' State Insurance Act 1948, providing for an insurance system for employees in cases of sickness, maternity, injury and death, the Plantations Labour Act 1951, which sought to regulate

\footnotetext{
${ }^{53}$ See Sankaran, above n. 14. See further nn. 179-182 below, and associated discussion. Some detailed examples of the complexity and rigidity of various labour law regulations are provided in B. Debroy, 'Issues in Labour Law Reform' in B. Debroy and P. D. Kaushik (eds.), Reforming the Labour Market, Academic Foundation, New Delhi, 2005, at pp. 42-55.

${ }^{54}$ Ornati, above n. 9, at p. 92.

${ }^{55}$ The Indian Constitution 1950 contains specific goals relating to labour, including the 'right to work', 'just and humane conditions of work', a 'living wage' and a 'decent standard of life' in addition to the right to form trade unions: see Constitution of India 1949 ss. 14, 15, 19, 39, 41, 43 and 43A in particular. For further discussion see R. Gopalakrishnan, 'Enforcing Labour Rights Through Human Rights Norms: The Approach of the Supreme Court of India' in C. Fenwick and T. Novitz (eds.), Human Rights at Work: Perspectives on Law and Regulation, Hart Publishing, Oxford and Portland, Oregon, 2010.
} 
conditions of work and provide welfare measures for India's high employment industries in tea and rubber plantations, and the Employees' Provident Fund and Miscellaneous Provisions Act 1952, one of the most important pieces of legislation in India's social security system.

It follows from what we have said earlier, however, that this period did not mark out a completely new approach to the issue of labour regulation in India. When it came to the regulation of collective labour relations in particular, the restrictive policies of government control which had characterised the colonial and immediate post-war period continued to hold sway. As various authorities have noted, the major influence on the formation of postindependence labour and economic policy was the priority given to government-directed 'nation building' - in which the need for trade union co-operation in securing industrial peace and labour support for industrialisation and economic development (economic nationalism) was paramount. ${ }^{56}$

Consequently the development of labour law in India continued to follow the dual pattern already identified. In support of the state planned and organised economy, ${ }^{57}$ the Indian government continued its strong interventionist role in industrial relations. The laws regulating trade unions and industrial disputes remained largely fixed on the model set by the legislation introduced over the period from 1926 to $1947,{ }^{58}$ and this in turn had certain implications for the Indian industrial relations system. While trade union organisation was legally sanctioned, collective bargaining (at least nominally) 'recognised', 59 and strikes and

\footnotetext{
${ }^{56}$ C. P. Thakur, Labour Policy and Legal Framework in India: A Review, Institute for Studies in Industrial Development, New Delhi, 2008, at p.8; Sundar, above n. 15, at pp. 920-921; Amjad, above n. 14, at p. 133; S. Ghose, 'Alternate Dispute Settlement Mechanisms in India - A Study of Industrial Adjudication' in A. Sivananthiran and C. S. Venkata Ratnam (eds.), Prevention and Settlement of Disputes in India, ILO, New Delhi, 2003, at p. 83; Sankaran, above n. 14, at pp. 226-227. Such an outlook has retained currency even in more recent times: see C.S. Venkata Ratnam (ed.), Industrial Relations in Indian States, Indian Industrial Relations Association/Global Business Press, New Delhi, 1996; Thomas, above n. 8.

${ }^{57}$ In the early period of political independence the Indian government established strong controls over the nation's economy in an avowedly 'socialistic' stance. This included the establishment of state monopolies or controls over industries considered vital to the development of the economy. This policy was formulated as part of the 1948 Industrial Policy Resolution and articulated in various Five Year plans introduced sequentially from the late 1940s onwards. In 1956 the industries brought under the control of the Indian government were expanded considerably, and included, among others, iron and steel, transport, arms and defence equipment, mining, electrical power, and telecommunications. The government's policy also included various supports for the development of private industry including tariff protection. See generally, A. S. Mathur, Labour Policy and Industrial Relations in India, Ram Prasad and Sons, Agra, 1968, at ch. 2; R. Mohan, 'Industrial Policy and Controls' in B. Jalan (ed.), The Indian Economy: Problems and Prospects, Penguin, New Delhi, 2004.

${ }^{58}$ Attempts in the post-war period to alter the law to provide for a more collective bargaining-oriented system were unsuccessful: see Sundar, above n. 15, at p. 922.

${ }^{59}$ At least to the extent that a 'settlement' arrived at through a direct bargaining process was recognised pursuant to a 1956 amendment to the Industrial Disputes Act 1947: viz. a written agreement 'between the employer and the workmen, arrived at otherwise than in the course of conciliation proceedings' (s. 18(1) of the $A c t)$. Such a settlement has to be filed with the appropriate authorities. This was in no sense a commitment by
} 
lockouts to a degree legalised and regulated, the level of state intervention in the actual industrial relations process, and the emphasis given to the maintenance of 'industrial peace, ${ }^{, 60}$ effectively circumscribed the possibility that collective bargaining might develop as the primary form of industrial relations in India ${ }^{61}$ : in effect '[c]ollective bargaining was held to be incompatible with economic planning, ${ }^{62}$

Overall the law on bargaining has changed little since these formative days, although in an important amendment to the Trade Union Act in 2001 it was provided that trade unions were required to have at least 100 members or to represent at least $10 \%$ of the workforce in order to secure registration under the Act, thereby making the formation and legalisation of unions far more onerous than had previously been the case. ${ }^{63}$ As noted earlier, some States did move to provide unions with a right to recognition, and some subsequent legislation made the refusal to bargain on the part of an employer an 'unfair labour practice', more or less making the duty to bargain legally obligatory. Probably the best example of this legislation is the Maharashtra Recognition of Unions and Prevention of Unfair Labour Practices Act 1971, which supplemented the Industrial Relations Act 1946 of Bombay, ${ }^{64}$ although that legislation was limited in its application to nine industries only. In 1982 the Indian Central government amended the Industrial Disputes Act of 1947 introducing the concept of the 'unfair labour practice' into national labour law. ${ }^{65}$ This legislation outlawed various practices by employers,

the Indian government to the pursuit of a 'collective bargaining'-led industrial relations policy, merely a recognition and sanctioning of what might transpire in the settlement of a dispute.

${ }^{60}$ Thakur, above n. 55, at p. 35. S. Visweswaiajah, 'Discretionary Referrals: Compulsory Adjudication and the Industrial Disputes Act 1947' (1990) 32 Journal of the Indian Law Institute 1, at p. 3.

${ }^{61}$ See Johri, above n. 43, paras. 574-578; Sankaran, above n. 14, at pp. 238-239. The same point has been made about earlier legislation such as the Trade Disputes (Conciliation) Act 1934 of Bombay: see Kooiman, above n. 38, at p. 1817.

${ }^{62}$ Sundar, above n. 15, at p. 921. Collective bargaining in the 1950 s was often viewed in India as exhibiting 'the law of the jungle'; see E. A. Ramaswamy, Power and State, Oxford University Press, New Delhi, 1984, ch.2. As noted above (see n. 49) India has not ratified the ILO Convention on Freedom of Association and the Right to Organise (Convention 87), nor the Convention on the Right to Organize and Collective Bargaining (Convention 98). Legislation providing for the compulsory recognition of trade unions by employers upon order of a labour court was passed by the Indian Central government in the form of the Trade Unions (Amendment) Act in 1947. That legislation was largely based on the system of collective bargaining in the USA. However, the legislation was never given legal effect: see G. M. Advani, 'State Intervention in Labour Relations: Canada and India' (1961) 19 Faculty of Law Review (University of Toronto) 23, at p. 25, and, B. T. Kaul, 'Pitfalls in the Industrial Relations Law in India' in S. N. Singh (ed.), Law and Social Change: Essays on Labour Law and Welfare Research Methodology and Environmental Protection, P. G. Krishnan Memorial Foundation, Delhi, 1990, at p. 102.

${ }^{63}$ Trade Unions (Amendment) Act 2001 (Act 31 of 2001), s. 5 (which inserted s. 9A into the Trade Unions Act, 1926).

${ }^{64}$ For brief accounts of this legislation see Johri, above n. 43, para. 555; Sundar, above n. 52, at pp. 68-69.

${ }^{65}$ Industrial Disputes (Amendment) Act 1982. The proscribed 'unfair labour practices' are listed in the Fifth Schedule to the Industrial Disputes Act 1947. Originally similar provisions had been proposed as part of amendments to the Trade Unions Act in 1947. However, these proposals came to nought in effect: see Advani, 
unions and workers designed to disrupt the legitimate processes of dispute settlement under the Act. The refusal by an employer to bargain collectively in good faith with the recognised trade union was listed as an unfair practice. Whilst on its face this provision might seem to have amounted to a major breakthrough in collective bargaining law in India, it does not appear to be regarded as particularly important by Indian labour law scholars, ${ }^{66}$ perhaps principally because it has had little impact in practice. What collective bargaining there is in India, and it does exist at all levels and across many industries, ${ }^{67}$ has evolved in a de facto sense, and, as noted earlier, has been largely limited to the public, and corporate, ${ }^{68}$ sectors of the economy. In the mid-1990s the proportion of Indian workers covered by collective bargaining agreements was estimated to be lower than five per cent. ${ }^{69}$

On the other hand, Indian labour law continued to develop in a second dimension; that is, in respect of the relations between the employer and the individual worker. Here we can identify two main categories of intervention. The first concerns the continued regulation for protective labour standards which took place at both Central and State levels. ${ }^{70}$ We have already noted the continuation of this pattern in the post-World War Two period, and, as Sundar has pointed out, ${ }^{71}$ the ongoing regulation for minimum wages, equal pay, social security and insurance, maternity benefits, health and safety, leave and holidays, housing and so on, occupied much of the regulatory space which was taken up in the contents of collective agreements in industrialised Western countries.

The second area of development concerns employment security. Originally the termination of, or dismissal from, employment was not an appropriate subject of an individual 'industrial dispute' pursuant to the Industrial Disputes Act 1947, and there was thus little limitation on the employer's right to fire an employee as it saw fit, ${ }^{72}$ other than a requirement that appropriate notice be given. ${ }^{73}$ Nor did the legislation place limitations upon the power of the

above n. 62 at pp. 24-25; C. Myers, Labor Problems in the Industrialization of India, Harvard University Press, Cambridge Massachusetts, 1958, at ch. 8 .

${ }^{66}$ For example, it is not mentioned in Amjad's brief discussion of the law on unfair labour practices: see Amjad, above n. 14, at ch. 12; and it is dismissed as unimportant in Johri, above n. 43, at para. 634.

${ }^{67}$ See generally C. S. Venkata Ratnam, 'Economic Liberalization and the Transformation of Industrial Relations Policies in India' in A. Verma, T. A. Kochan and R. D. Lansbury (eds.), Employment Relations in the Growing

Asian Economies, Routledge, London, 1995, at pp. 281-285.

${ }^{68}$ See above n. 49.

${ }^{69}$ International Labour Organization, Organization, Bargaining and Dialogue for Development in a Globalizing World, Governing Body, $279^{\text {th }}$ Session, Geneva, 2000.

${ }^{70}$ See generally Menon, above n. 12.

${ }^{71}$ Sundar, above n. 15, at p. 921.

${ }^{72}$ Amjad, above n. 14, at pp. 98-99.

${ }^{73}$ Notice was required under the Industrial Employment (Standing Orders) Act 1946. 
employer to retrench or lay off redundant workers. However, pursuant to amendments to the Industrial Disputes Act in 1953, 1976 and 1982 the Central government began gradually to introduce important new regulations pertaining to retrenchments, lay-offs, and plant and industry closures. These regulations, including the all important Chapters VA and VB of the Act required, inter alia, permission by the appropriate authorities for mass redundancies and firm closures, minimum notice periods and further relief in the form of compensation. ${ }^{74}$

As far as individual dismissals are concerned, a 1965 amendment to the Industrial Disputes Act created a right in an individual employee to notify an 'industrial dispute' over his or her discharge, dismissal, retrenchment or other form of termination, whether or not that person was represented by a trade union. ${ }^{75}$ A subsequent amendment, in 1971, empowered the Industrial Tribunals and the Labour Court to investigate the dismissal of employees, and make appropriate orders, including reinstatement and compensation, where the dismissal was found to be unfair. ${ }^{76}$ As a consequence of these legal changes, the Labour Court and other tribunals developed a general broad discretion to review the dismissal of workers and to award relief according to notions of substantive and procedural injustice. In 1976, amendments to the Act substantially increased (from one month to three months) the amount of notice required to be given to certain categories of employees who had been in continuous service for at least one year, ${ }^{77}$ and prohibited the dismissal of workers by way retrenchment, lay-off, or industry closure in factories, mines and plantations employing 300 or more persons (later reduced to 100 or more in 1982) without permission of the appropriate government.

Other legislation introduced in the 1970s and into the 1980s consolidated this evolving protective framework of laws for employees engaged in the regulated (formal) ${ }^{78}$ sectors of the economy. Aside from further strengthening the law on dismissal, major legislation was introduced by the Central government in 1970 which strictly limited and regulated the use of contract and agency labour. ${ }^{79}$ Further, the Industrial Disputes (Amendment) Act of 1982, in addition to declaring certain collective behaviours by both employers and unions to be 'unfair labour practices' declared certain hiring practices, such as the continuing employment of

\footnotetext{
${ }^{74}$ See Johri, above n. 43, at Part II, Ch. 5.

${ }^{75}$ Industrial Disputes (Amendment) Act 1965, s. 2-A.

${ }^{76}$ See Johri, above n. 43, at Part I, Ch. 4.

77 This is now Chapter VB of the Industrial Disputes Act 1947.

${ }^{78}$ See n. 50 above and n. 184 below and associated discussion.

${ }^{79}$ The Contract Labour (Regulation and Abolition) Act 1970.
} 
workers on casual or temporary contracts with 'the object of depriving them of the status and privileges of permanent workmen', also to be unfair. ${ }^{80}$

Overall, then, the post-Independence period was, at least at the level of the individual worker in the regulated sector, clearly a period of important consolidation in employment protection. Not only the Central government, but also several of the State governments, played an important role in this development. ${ }^{81}$ In his study of the impact of Indian labour regulation on unemployment, Sarkar notes that in the period from 1970 to 2006 there were changes in only nine of 40 variables used in one quantitative study of Indian labour law. ${ }^{82}$ Of those 9 changed variables, 8 were numerically assessed to have been of advantage to labour and thus of disadvantage to management. Of those 8,7 pertained to the individual employment rights (employment status and security) of workers. What this says about the overall protective strength of Indian labour law is problematical, and we address this issue in the following section of the paper. But what it does confirm is that in the long sweep of post-war evolution in Indian labour law, Indian governments were concerned principally with the construction and maintenance of a 'floor of rights' for certain classes of labour, and at the same time restricting the industrial, if not the political, development of collective labour influence.

\section{The Struggle for Liberalisation: Post-1990 ${ }^{83}$}

Whatever might be said with accuracy about the protective qualities of the Indian labour law system, it is certainly the case that there is a widespread perception that both the extent and content of regulation in the Indian labour market has placed severe restrictions on the capacity of the Indian economy to develop, particularly in the context of economic globalisation. ${ }^{84}$ References are constantly made to the volume and severity of the regulatory

\footnotetext{
${ }^{80}$ The Industrial Relations Act 1947, Fifth Schedule.

${ }^{81}$ For example, in relation to termination of service see Johri, above n. 43, at paras. 197-198; in relation to unfair practices see Johri, above n. 43, paras 206-208; and in relation to lay-offs and retrenchments Johri, above n. 43, paras. 522-523.

${ }^{82}$ P. Sarkar, 'Indian Labour Regulation and its Impact on Unemployment: A Leximetric Study, 1970-2006' Unpublished Paper, Economics Department, Jadavpur University, Kolkata, 2011. An electronic version is available at http://ssrn.com/abstract $=1913609$. The dataset has been compiled by the Centre for Business Research at the University of Cambridge : see http://www.cbr.cam.ac.uk/research/programme2/project220output.htm.

${ }^{83}$ See generally, Ratnam, above n. 67.

${ }^{84}$ See generally, Sankaran, above n. 14, at pp. 241-244; Sundar, above n. 52, ch. 1; Amjad, above n. 14, at pp. 170-173; R. Jenkins, 'Labor Policy and the Second Generation of Economic Reform in India' (2004) 3 India Review 333, at p. 333.
} 
framework and the arcane nature of the rules and institutions constituting Indian labour law. ${ }^{85}$ As noted earlier India has well in excess of 150 separate laws ${ }^{86}$ governing the labour market and the workforce, many of which overlap, deviate from Central principles or are perceived to be simply out of date. ${ }^{87}$ This perception of 'over-regulation' ${ }^{88}$ has given rise to agitation from many sources ${ }^{89}$ for the various Indian governments to roll back their regulation of labour and workplaces, particularly those laws which impact upon the capacity of enterprises to hire and fire more easily, and to engage labour on more flexible arrangements, ${ }^{90}$ and those requiring the payment of minimum wages. ${ }^{91}$ At the same time, this pressure for reform has been strongly resisted by the labour movement generally. ${ }^{92}$

In part this comes down to disagreement over evidence, and in part over ideology. ${ }^{93}$ Certainly there are legitimate doubts raised in the literature on the accuracy of the supposed connection

\footnotetext{
${ }^{85}$ For a general overview see A. Ahsan, C. Pages and T. Roy, 'Legislation, Enforcement and Adjudication in Indian Labor Markets: Origins, Consequences and the Way Forward' in D. Mazumdar and S. Sarkar (eds.), Globalization, Labour Markets and Inequality in India, International Development Research Centre, Ottawa, 2008, at ch. 11.

${ }^{86}$ Estimates vary; compare Sundar above n. 52, at p. 5, D. S. Leelavathi, 'The Contours of Labour Sector Reforms in India' in G. Saibaba (ed.), Labour and Development in Twenty First Century, Serials Publications, New Delhi, 2005, at p. 378, and T. S. Papola and J. Pais, 'Debate on Labour Market Reforms in India: A Case of Misplaced Focus' (2007) 50 Indian Journal of Labour Economics 183 at p. 196; F. L. Cooke, 'Employment Relations in China and India' in M. Barry and A. Wilkinson (eds.), Research Handbook of Comparative Employment Relations, Edward Elgar, Cheltenham U.K., 2011, at pp. 188-189. According to the Indian Labour Bureau, in 2003 there were 236 important labour related statutes in India, 76 at Central level, and 160 at State level: Labour Bureau, India Labour Year Book, Ministry of Labour and Employment, Government of India, New Delhi, 2004. As a result of this voluminous regulation a typical factory or business establishment might have to deal with about 25 or so pieces of central government legislation and perhaps a further 10-15 pieces of state legislation.

${ }^{87}$ See Sundar, above n. 52, at p. 5.

${ }^{88}$ See Ahsan, Pages and Roy, above n. 85, at p. 248, Papola and Pais, above n. 86, at p. 196.

${ }^{89}$ This includes both international and national bodies. The World Economic Forum has identified restrictive labour regulation as a major factor in limiting the ease of doing business in India, and India is ranked 116th of 155 countries in the 'ease of hiring and firing' workers according to the World Bank's Doing Business Survey of 2006: see Sundar, above n. 52, at pp. 6-9. In the World Bank's Doing Business Survey of 2005 India was also ranked poorly when compared with many other countries on other matters such as the restriction on increasing or reducing the number of working hours: V. N. Prasad, Labour Regulation in Small Enterprises: Coverage and Impact, Institute for Studies in Industrial Development, New Delhi, 2008, pp. 4-5. Sankaran notes that the Second National Commission on Labour, Ministry of Labour, Government of India, 2002, also recommended changes to the laws on lay-offs and retrenchment: see Sankaran, above n. 14, at p. 242.

${ }^{90}$ Ahsan, Pages and Roy instance a series of provisions in the Industrial Disputes Act as being particularly noxious to employment creation. These are: s. 11-A which permits Labour Courts to modify retrenchment orders (including disciplinary dismissals); s. 25-O which makes it mandatory for employers to refer cases of business closure to state governments and s. $25-\mathrm{F}$ and $25-\mathrm{G}$ which, according to the authors, 'practically disallow retrenchments or lay-offs without compensation except when the owner dies'. The authors also declare Chapter VB of the Act (see above n. 74 and associated text) to be 'more restrictive than anywhere else in the world': Ahsan, Pages and Roy, above n. 85, at pp. 264-273.

${ }^{91}$ For details on the kind of reforms under consideration over the past two decades see Leelavathi, above n. 86. See also the works cited in $\mathrm{n} .77$ above.

${ }^{92}$ See Sankaran, above n. 14, at p. 242; Johri, above n. 43, paras. 64-66.

${ }^{93}$ See T. S. Papola and J. Pais, above n. 86, at p. 186; T. S. Papola, J. Pais and P. P. Sahu, Labour Regulation in Indian Industry: Towards a Rational and Equitable Framework, Institute for Studies in Industrial Development,
} 
between Indian labour law and the perceived 'inflexibility' of the Indian labour market: at the very least the evidence is considered slight, ambiguous or both. ${ }^{94}$ However, this question is not a core concern for us here, although we do return to the issue in the next section of the paper. Rather, we are interested in whether, and if so to what extent, labour law in India has undergone a period of modification in response to liberalisation, and what form that change might have taken.

The immediate catalyst for action in labour market reform in India is grounded in the state of economic crisis which confronted the country in the late 1980s. It is not necessary for us to detail these problems here, but it is important to note that the government was obliged to accept a readjustment package proposed by the World Bank and the International Monetary Fund which required certain steps to be taken to liberalise the economy. ${ }^{95}$ As part of this 'New Industrial Policy' the Indian government was committed to reducing the number of industry sectors under the monopoly or control of the state, abolishing the need for government approval for new investment in specific sectors of the economy, and generally winding back the public sector. Unprofitable state industries were to be wound back or closed down, and a more flexible system for the licensing of new businesses introduced. ${ }^{96}$ A shift to a less regulated labour market, particularly in relation to the tight controls exercised (at least in the organised sector) over dismissals and redundancies and the use of contract labour, was inevitably part of this policy. ${ }^{97}$ Workers were to be disciplined by the market rather than by state control. $^{98}$

New Delhi, 2008, at p. 107. See also Sankaran, above n. 14, at pp. 242-244; Sundar, above n. 52, at pp. 8-10; and T. Deb, 'Reforming Labour Legislation on Working Conditions for Competitive Advantage: An Empirical Study' (2010) 46 Indian Journal of Industrial Relations 201.

${ }^{94}$ See Sankaran, above n. 14, at pp. 242-244; P. Fallon and R. Lucas, 'Job Security Regulations and the Dynamic Demand for Labor in India and Zimbabwe' (1993) 40 Journal of Development Economics 241; Jenkins, above n. 84; T. Besley and R. Burgess, 'Can Regulation Hinder Economic Performance? Evidence from India' (2004) 119 Quarterly Journal of Economics 91; S. D. Roy, 'Employment Dynamics in Indian Industry: Adjustment Lags and the Impact of Job Security Regulations (2004) 73 Journal of Development Economics 233; T. Anant, R. Hasan, P. Mohopatra, R. Nagaraj and S. Sasikumar, 'Labour Markets in India: Issues and Perspectives' in J. Felipe and R. Hasan (eds.), Labour Markets in India: Issues and Perspectives, Palgrave Macmillan, Basingstoke, 2006; A. Bhattacharjea, 'Labour Market Regulation and Industrial Performance in India: A Critical Review of the Empirical Evidence' (2006) 49 Indian Journal of Labour Economics 211; Ahsan, Pages and Roy, above n. 85; Papola and Pais, above n. 86.

${ }^{95}$ See Candland, above n. 11, at pp. 99-100; Jenkins, above n. 84.

${ }^{96}$ For some general details on this policy, and its implications for industrial relations in India see J. S. Sodhi, 'New Economic Policies and Their Impact on Industrial Relations' (1993) 29 Indian Journal of Industrial Relations 31. See also A. Kotwal, B. Ramaswami and W. Wadhwa, 'Economic Liberalization and Indian Economic Growth: What's the Evidence?' (2011) 49 Journal of Economic Literature 1152.

${ }^{97}$ Jenkins, above n. 84; Papola and Pais, above n. 86.

${ }^{98}$ Sundar, above n. 15 , at p. 931. 
Generally, successive governments, through various policy pronouncements, have continued to espouse support for these policies, including those designed to effect adjustment in the labour market and employment relations. ${ }^{99}$ But the degree to which these policies have achieved real outcomes, and the manner of their doing so, have remained unclear and contentious. Consequent neo-liberal reform measures, according to one account, have included policies to '...weaken union power, outlaw strikes, individualize labour relations, privatize public enterprises, dilute labour laws, freedom to hire and fire and close undertakings [sic.], removal of prohibition of contract labour [sic.], freedom to introduce technical changes [sic.], repeal of legal provisions relating to bonus [sic.] and so on'. ${ }^{100}$ But nevertheless, there is considerable caution, if not to say scepticism, over how much progress has been made in following these policies through. ${ }^{101}$

The main reason for caution seems to be linked with both the political and legal strategies being adopted in the slow liberalisation process. By and large the labour reform policies have been pursued not through major legislative change, but through a 'less direct' and more piecemeal approach. ${ }^{102}$ One critical explanation for this lies in the fact that various political and labour alliances across different political parties are usually sufficient to block major labour law reform. ${ }^{103}$ Put another way: 'Labour law reforms have traditionally worked in India when approved through the tripartite route'. ${ }^{104}$ Traditionally the Indian union movement was very powerful in political terms by virtue of its incorporation into the party political process, and although this power had reached its high point by about the mid-1970s, and membership decline has since impacted upon its capacity to resist change, ${ }^{105}$ overall most authorities still rank the political influence of the union movement as critical. ${ }^{106}$

This has led, then, to what has been described as a gradual approach to liberalisation. ${ }^{107}$ Although there have been some labour policy initiatives at the Central government level, ${ }^{108}$

\footnotetext{
${ }^{99}$ See Leelavathi, above n. 86.

${ }^{100}$ Sundar, above n. 15 , at p. 930.

${ }^{101}$ See, for example, the observations by Ahsan, Pages and Roy, above n. 85, at pp. 247-250.

${ }^{102}$ See Jenkins, above n. 84; Sundar, above n. 15, at p. 932. Jenkins labels this 'reform by stealth'.

${ }^{103}$ See Sundar, above n. 15, at p. 932; Jenkins, above n. 84, at pp. 344ff.

${ }^{104}$ Sankaran, above n. 14, at p. 245; C. K. Johri, 'Industrial Relations as Regulated by Law: Suggestions for Change' (1996) 31 Indian Journal of Industrial Relations 439; Anon. 'Wartime Developments in Trade Union Organisation in India' (1946) 53 International Labour Review 349.

${ }^{105}$ See Papola and Pais, above n. 86, at p. 193.

${ }^{106}$ See Jenkins, above n. 84; Sundar, above n. 15; Candland, above n. 11, at pp. 30-31.

${ }^{107}$ Sundar, above n. 15, at p. 932; Jenkins, above n. 84, at p. 340.

${ }^{108}$ The Central government introduced the concept of Special Economic Zones as part of its Export-Import Policy 1997-2002. It was anticipated that this would lead to the provision of more flexible work laws to attract capital, but see n. 112 below and associated text. The Central government also appointed a Second National
} 
including, for example, various proposals and Bills for the protection of workers in the unorganised sector, ${ }^{109}$ the most important and ongoing movements towards liberalisation in labour law have taken place at the State government level. Jenkins has pointed out that India's Federal political structure has lent itself to a more gradual reform agenda in three specific ways. First competition between the various States for investment has led to legal change on a State by State basis hence avoiding the need for an all embracing national reform of labour law. In order to attract investment, often State governments provide assurances to investors that certain inconvenient labour standards will not be enforced. Secondly, dealing with the issues on a State by State basis also waters down the degree of political resistance from unions and other opposition forces. Third, State reforms may act as models for changes in other States, or even to provide some leadership for reform at the Central government level. ${ }^{110}$

It is important, therefore, in understanding whatever limited progress has been achieved in the liberalisation of Indian labour law and regulation, to look closely at the developments in several of the important States. It is first necessary to note that even here many of the bolder proposals for reform have failed to pass into law. The State of Maharashtra is a good case in point, with major reform proposals being presented by the Director of Industries in 2000, and through an Industrial Policy Statement in 2001. Among these proposals were changes to minimum wage laws, retrenchment laws, laws relating to the inspection of work premises, and laws pertaining to the size of plants excluded from regulation. None of these changes were implemented due to opposition from trade union and political interests. ${ }^{111}$ Similarly, attempts by the Maharashtra State government (and other States) to introduce more flexible 'hire and fire' laws into the businesses situated in the state's Special Economic Zones has generally been met with a negative response from the Central authorities (although it is necessary to note that in practice labour laws are rarely enforced in these zones, and thus rarely, if ever, restrict market operations despite the limitations inherent in the formal law). ${ }^{112}$ On the other hand there are also examples of successful modifications being made to central

Commission on Labour in 1999 with a view to rationalising India's labour laws. The Commission's Report was released in 2002. This went so far as to propose a new model of labour law for the country, and also proposed comprehensive legislation to ensure a minimum level of protection to workers engaged in the unorganised sectors of the economy (see R. Datt, 'National Commission on Labour and Review of Labour Laws' (2003) 46 Indian Journal of Labour Economics 109) but nothing of much practical import eventuated from this exercise. Other initiatives have included policy changes on privatisations and tariff reductions: see Jenkins, above n. 84 .

${ }^{109}$ Prasad, above n. 89, pp. 49-50.

${ }^{110}$ See Jenkins, above n. 84, at pp. 341-343.

${ }^{111}$ See Sundar, above n. 52, at pp. 148-152.

112 Sundar, above n. 52, at p. 154. 
labour laws by some provincial governments, the State of Andhra Pradesh being a case in point. $^{113}$

In general terms the liberalisation process in the labour laws of the Indian States has included the relaxation of laws against the employment of women at night, greater ease in shift working, and greater freedom for the use of contract labour. ${ }^{114}$ According to one source, the use of contract labour, and the sub-contracting of non-core activities to other firms, increased substantially during the $1990 \mathrm{~s}$, though this increase was more pronounced in some States than others. ${ }^{115}$ On the other hand, despite the general laxity of enforcement in labour law, the laws on retrenchment continue to be comparatively strictly implemented. ${ }^{116}$

Other minor changes include matters such as the minimisation of workplace inspections and technical changes to the administration of workplaces and keeping of records required under various pieces of factory legislation and so on. ${ }^{117}$ Much of this change has been facilitated through administrative procedure rather than formal legal repeal and enactment. ${ }^{118}$ According to one recent study, while India's job security laws have remained fairly stable for regular contracts (i.e. ongoing contracts in the organised or formal sector) the system is now more flexible in relation to temporary and fixed-term contracts. This reflects the fact that 'the main area of labour law reform that has come about in recent years, allowing employees to work on temporary work agency contracts to carry out a range of "non-core" activities, a concept that is defined in various ways across states ... Standard fixed-term contracts are allowed for white-collar workers as well as, in principle, for regular workers'. ${ }^{119}$

However, despite these shifts in labour law at the State level, it remains the case that the liberalisation process has produced modest outcomes at best. An OECD study reported by

\footnotetext{
${ }^{113}$ For discussion see D. N. Reddy, Labour Regulation, Industrial Growth and Employment: A Study of Recent Trends in Andhra Pradesh, Institute for Studies in Industrial Development, New Delhi, 2008, pp. 42-47.

${ }^{114}$ For example, as of January 2005 the State of Maharashtra had extended more than 500 exemptions under its Shops and Commercial Establishments Act, which facilitated greater flexibility in software, information technology and biotechnology businesses in relation to working days and hours, and the employment of women at night: see S. Sundar, Current State and Evolution of Industrial Relations in Maharashtra, ILO, Geneva, 2009. There were similar exemptions extended in the software industry in the State of Tamil Nadu: see S. Sundar, Current State and Evolution of Industrial Relations in Tamil Nadu, ILO, Geneva, 2010. See also C. Penfold, 'Off-Shored Services Workers: Labour Law and Practice in India' (2008) 19 The Economic and Labour Relations Review 91, at p. 96.

${ }_{115}^{115}$ Ahsan, Pages and Roy, above n. 85, at p. 261.

${ }^{116}$ Ibid.

${ }^{117}$ See Sundar, above n. 15, at p. 931; Prasad, above n. 89, at pp. 50-52.

${ }^{118}$ Some examples are furnished in Reddy, above n. 113, at pp. 46-47.

${ }^{119}$ S. Dougherty, 'Labour Regulation and Employment Dynamics at the State Level in India' (2009) 1 Review of Market Integration 295 at p. 307. It is important to note here that the expression 'non-core' denotes prohibited categories of employment in terms of the Contract Labour Act 1971.
} 
Dougherty examined eight sets of regulatory variables (totalling fifty separate subject areas) for potential reform lightening the regulatory burden upon businesses across 21 Indian States. In keeping with our earlier observations, the largest number of reforms related to contract labour, but even so, there had only been reform in about half of the subject areas pertaining to this form of employment. No State had a score of much more than 50 per cent in terms of change in possible reform areas, and in seven of the 50 subject areas no more than two States had made any reforms at all. Areas of regulation showing little change across the 21 States included collective lay-offs, the regulation of working hours, union recognition and reductions in the numbers of inspections. ${ }^{120}$

\section{Quality, Purpose and Impact in Indian Labour Law}

There are always difficulties, we suggest, in interpreting the purpose and role of labour law systems in any given society. Labour law, more than many other areas of regulatory policy, may have more immediate and fundamental implications for social and economic stability and progress, and legal formality may not always fully express or capture the kinds of compromises which inevitably exist in relations between capital and labour, and in the regulation of labour markets.

In our necessarily brief overview of the evolution of labour law in India, we have pointed to various anomalies and problems which require further elaboration and discussion. First, though, it is necessary for us to clarify one or two matters going to the legal foundations of the Indian labour law system. As we have noted there is a continued relevance of some nonlegal socio-cultural relations in the organisation and practices of Indian labour markets to the present day. ${ }^{121}$ However, formal labour law in India is firmly based on Western values and concepts, much of it derived from International Labour Organisation standards. It has evolved from early penal provisions on labour, through to the extension of protective labour conditions of work, and the rights of labour to security in a broader social sense. Moreover, Indian labour law has recognised and legitimated trade unions and their activities and established procedures for the settlement of industrial disputes. While there may be problems

\footnotetext{
${ }^{120}$ See Dougherty, above n. 119, at pp. 308-312.

${ }^{121}$ See above n. 16.
} 
in accurately categorising India according to the indicators used in the 'legal origins' labour law discourse, Indian labour law is Western in conception and (at least nominal) operation. ${ }^{122}$

This suggests, then, that we are able to evaluate the role and impact of Indian labour law accordingly. It is necessary, of course, to recognise that social, economic, political and cultural contexts will inevitably have a heavy bearing upon how labour laws are received, adapted and given effect in particular socio-economic contexts, ${ }^{123}$ but it is also important to recognise that such laws are introduced usually not to replicate or reproduce existing social and economic relations, but at least in part to replace or alter them.

In the Indian case we must suppose that its labour law values, as articulated in its Constitution and its originating economic policies in the post-independence period, were constructed and evolved in the supposition that the country's socio-economic path would follow a similar trajectory to the process of industrialisation, urbanisation and formalisation that occurred in the developed economies of Western countries.

\section{$* * * *$}

One of the most prominent aspects of the debate over the development of Indian labour law is the widely varying viewpoints taken of its qualities and effects. Much of this concerns what DeSousa has labelled the apparent 'disjunctures' between the stated objectives of labour law regulation and the 'actual practices' of industrial relations, ${ }^{124}$ but there are other discordant perspectives in evidence.

For example, Indian labour law has been labelled 'progressive', ${ }^{125}$ and identified as one of the country's most important institutions. ${ }^{126}$ Yet, on the other hand, more recently Indian labour law has been described as mired in old-fashioned, out-of-touch regulation, ${ }^{127}$ as 'bizarre', ${ }^{128}$ and the industrial relations system that it regulates as 'absurd'. ${ }^{129}$ Indeed the complaints about the quality and effects of Indian labour law are extensive to say the least. There are said to be too many laws. The law is said to lack uniformity, to be overly detailed, to be inconsistent,

\footnotetext{
${ }^{122}$ See below nn 171-177.

${ }^{123}$ S. Cooney, T. Lindsey, R. Mitchell and Y. Zhu (eds.), Law and Labour Market Regulation in East Asia, Routledge, London, 2002; P. Nicholson and S. Biddulph (eds.), Examining Practice, Interrogating Theory: Comparative Legal Studies in Asia, Brill, Leiden, 2008.

${ }^{124}$ See DeSousa, above n. 6.

${ }^{125}$ See Menon, above n. 12, at pp. 570-571.

${ }^{126}$ See Vaid, above n. 7.

${ }^{127}$ See Sundar, above n. 52, at p. 6; Sankaran, above n. 14.

${ }^{128}$ See C. Navin, 'Legal Regulations of Labour Market' (1999) 42 Indian Journal of Labour Economics 855.

${ }^{129}$ See Hill, above n. 15.
} 
ambiguous, and poorly co-ordinated in policy terms. The whole system is said to be overregulated, and at the same time to be largely ineffective. ${ }^{130}$ Attempts to integrate and consolidate Indian labour law into a single Labour Code, such as that initiated by the National Labour Law Association in 1994, have been unsuccessful.

As we noted at the outset of this paper, all of this suggests the need for a much more detailed survey of the role of the state, and its legal policies, over the course of Indian industrialisation in the post -independence period. But for the more limited purposes of this present project we aim to deal with two key questions concerning the purposes of state policy in Indian labour law and the impact of those policies. A broader and lengthier analysis will have to await further work.

As we have noted, the most common and influential view taken of the state's role in the Indian political economy is one which emphasises the dominance of the state's interests in shaping the Indian economy and the co-ordination of labour and capital to that end. ${ }^{131}$ These arrangements have been described in terms of 'state socialism' and 'corporatism, ${ }^{132}$ and the analyses point to the strong state involvement in economic planning and development, a dominant role for the public sector, and strong regulation of the private sector. Under this model, unions, labour and capital were drawn, or compelled, into ostensibly collaborative arrangements, ${ }^{133}$ rather than the conflict-based models that were embodied in the collective bargaining and arbitration systems of Western economies.

It is against this background that we can give some consideration to the specific objectives of the state in Indian labour law. In moulding the differing concerns of capital and labour to the interests of the Indian state, to what particular ends did the various Indian governments shape its labour laws and institutions? And how effective were they in that task?

The international literature concerned with the purposes of labour law suggests that there are numerous possible objectives underlying labour law systems, and that these may ebb and

\footnotetext{
${ }^{130}$ See Sundar, above n. 52, at p. 5; Papola and Pais, above n. 86; Ornati, above n. 9, pp. 82-83, 92-93; A. N. Sharma, 'Flexibility, Employment and Labour Market Reforms in India' (2006) 41 Economic and Political Weekly 2078; Bhattacherjee and Ackers, above n. 8, at p. 112; Sankaran, above n. 14, at p. 236; Ahsan, Pages and Roy, above n. 85.

${ }^{131}$ Candland, above n.11, at p.16.

${ }^{132}$ Sankaran, above n.14, at p. 227; Sundar, above n.15. Note that Sundar identifies different stages/varieties of corporatism in Indian industrial relations although the core principles remained the same throughout.

${ }^{133}$ This type of approach had already emerged during the war years if not earlier: see Anon, above n. 104.
} 
flow, and perhaps even change radically, in response to changing socio-economic contexts. ${ }^{134}$ It is not necessary for us to cover all of this ground here. We suggest that historically two core purposes have characterised the role of labour law in a very general sense. The first of these has been to protect the interests of workers in what is seen to be an unequal power relationship between labour and capital. The second has been to support, in various ways, the system of production and distribution, and hence economic development and social prosperity. As we have noted in Section 2 of this paper, the Indian state had already by the late 1940s and early-1950s constructed a substantial body of protective legislation, and the volume of regulation of this type continued to grow into the 1980 s, particularly in relation to occupational health and safety, equal opportunity, employment security, social insurance and other minimum standards. Alongside this regulation was a legislative system designed to settle industrial disputes and limit the economic damage of strikes and other forms of industrial action. In the Indian context these two strands of legislation have been described in the following terms:

Broadly the object of labour law is two-fold; (i) to improve the service conditions of industrial labour so as to provide for them the ordinary amenities of life, and (ii) by that process, to bring about industrial peace which would in turn, accelerate productivity in the country resulting in its prosperity which in turn, helps to impose the conditions of labour so that same [sic.] can be raised from the stage of minimum wage and passing through need-found [sic.] wage and fair wage reach the level of living wage [sic.]. ${ }^{135}$

The second question, with which this section of the paper is largely concerned, follows immediately from the first. If we are correct in taking these to be the two main goals of Indian labour law throughout its lengthy evolution, how effective has the law been in reaching those objectives? The question of impact (or effectiveness) is often an ignored issue in legal studies generally. While an examination of the formal institutions of labour law inevitably tells us something about the law's historical antecedents, its supposed purposes, the style of its regulation and the means of its enforcement, it cannot of itself contribute to a measure of how, and to what extent the rules apply, nor what effect it has on the behaviour and experience of the parties engaged in industrial relations and labour market arrangements.

\footnotetext{
${ }^{134}$ See, for example, G. Davidov and B. Langille (eds.), The Idea of Labour Law, Oxford University Press, Oxford, 2011.

${ }^{135}$ See Mishra, above n. 7, at p.10.
} 
There is extensive debate in the Indian economics and industrial relations literature about these matters generally, and here we draw upon this material as a means of making an assessment of the effectiveness of labour law across the two main goals identified above. Before turning to each of these specific matters in turn, however, it may be useful to make some observations about the effectiveness of Indian labour law in general.

It will have been evident from our foregoing discussion that notwithstanding the emergence of India as a modernising, industrialising state with impressive levels of economic growth, its labour law system is widely regarded as largely, if not wholly, ineffective. There are several grounds upon which such observations are based. First, India is still a very hierarchical society, and access to jobs is still heavily influenced by matters such as caste, sect and religion. This affects both the procurement of positions in the formal sector, and wage differentials in the regulated labour market in particular. ${ }^{136}$

Second, as we have also noted throughout, Indian labour law is limited in application by size of establishment, type of economic activity, type of employment relationship, type of employment position and so on. The immediate consequence of this is that the law has very limited application, and the great bulk of workers engaged in the informal sector are simply not regulated by any labour law at all. ${ }^{137}$

Thirdly, even where labour laws do apply in principle, the law is easy enough to evade in practice, ${ }^{138}$ and generally enforcement is very poor. According to many authorities there is

\footnotetext{
${ }^{136}$ See, for example, M. B. Das and P. V. Dutta, 'Does Caste Matter for Wages in the Indian Labour Market?' World Bank, 2007; Harriss-White and Gooptu, above n. 16; B. Banerjee and J. B Knight, 'Caste Discrimination in the Indian Urban Labour Market' (1985) 17 Journal of Development Economics 277; A. P. D'Costa, 'Geography, Uneven Development and Distributive Justice: The Political Economy of IT Growth in India' (2011) 4 Cambridge Journal of Regions, Economy and Society 237; A. P. D'Costa, 'Contemporary Capitalism and the Challenges for Inclusive Development in India', Paper presented at the Inclusive Growth in China and India: Role of Institution Building and Governance Workshop, School of Economics, University of Sydney, 2011; S. Damodaran, 'New Challenges to Regulation, the Record of Violations and the Responses in Globalised Labour Markets: The Indian Case', Paper presented at Conference on Regulating for a Fair Recovery Network, International Labour Office, Geneva, 6-8 July 2011. For an earlier, less pessimistic view of the influence of caste and other cultural norms influencing workplace regulation see M. D. Morris, 'Caste and the Evolution of the Industrial Workforce in India' (1960) 104 Proceedings of the American Philosophical Society 124.

137 'Take the labour laws... Their loopholes are big enough for the proverbial bus to be driven through...': See Harriss-White and Gooptu, above n.16, at p. 103.

${ }^{138}$ For examples, see M. Singh, 'Unorganised Industries: Conditions of Work and Labour Laws' (1988) 23 Indian Journal of Industrial Relations 373; T. Warnecke and A. de Ruyter, 'A Race to the Bottom? Variations Between States and Provinces in the Enforcement of Decent Work: A Comparative Study of Indonesia and India', paper presented at Conference on Regulating for a Fair Recovery Network, International Labour Office, Geneva, 6-8 July 2011; K. R. S. Sundar, 'Emerging Trends in Employment Relations in India' (2010) 45 Indian Journal of Industrial Relations 485.
} 
corruption and collusion between inspection agents and employers, ${ }^{139}$ there is an overall decline in the rate of inspections and prosecutions for breaches of the laws, ${ }^{140}$ and there are deficiencies in the qualities of inspectors. ${ }^{141}$ Against this, the overall weakness of the trade union movement, and the poor education of workers ${ }^{142}$ means that labour is unable to influence these outcomes to any marked degree.

It follows from these observations that far from regarding Indian labour law as one of the country's key institutions, as some have suggested, ${ }^{143}$ a more realistic appraisal would suggest that Indian labour law is, perhaps with some exceptions relating to specific types of protections, ${ }^{144}$ and in some particular regions where provincial governments have made the regulation of the informal sector and enforcement a special focus, ${ }^{145}$ not very important at all beyond a very small sector of the workforce. Clearly this has significant implications for the idea of labour law, and its effects in socio-economic terms, and we explore some of these issues in the following discussion.

\section{The Protection of Labour}

Both the support ostensibly offered by the Indian state towards labour, and the supposed long-run power and influence of the Indian union movement at large (at least until the mid$1970 \mathrm{~s}),{ }^{146}$ would tend to suggest that the Indian labour law framework has provided strong protection for labour vis-a-vis business interests, but in point of fact this issue has been strongly debated for decades, as we noted earlier. Beginning at least with the trade union and industrial disputes laws of the 1920s, through to the wartime legislation of the 1940s and beyond, trade union representatives and labour scholars have tended to characterise much of the Indian labour law framework, and the way that it operates, as highly restrictive, and at

\footnotetext{
${ }^{139}$ See Navin, above n. 128; Penfold above n. 114; Ahsan, Pages and Roy above n. 85; Warnecke and de Ruyter above n. 138; H. S. Sandhu and M. K. Sharma, "'Decent Work" and Labour Regulatory Mechanism: A Study of the State of Punjab (India)', paper presented at Conference on Regulating for a Fair Recovery Network, International Labour Office, Geneva, 6-8 July 2011.

${ }^{140}$ See Reddy, above n. 113; J. Pais, Effectiveness of Labour Regulations in Indian Industry, Institute for Studies in Industrial Development, New Delhi, 2008.; Ahsan, Pages and Roy, above n. 85.

${ }^{141}$ S. E. Kauff, 'Compulsory Disclosure of Hazards, Emergency Planning, and Training in the Workplace: India's Factories Act and the United States' Hazard Communication Standard' (1996) 17 Comparative Labor Law Journal 565, at p. 587.

${ }^{142}$ Kauff, above n. 141, at pp. 573-575 and p. 587.

${ }^{143}$ See Vaid, above n. 7.

${ }^{144}$ For an example in relation to retrenchments, see Ahsan, Pages and Roy, above n. 85

${ }^{145}$ See Warnecke and de Ruyter, above n. 138; J. Folkerth and T. Warnecke, 'Organizing Informal Labor in India and Indonesia: A Discussion of Barriers and Best Practices of Overcoming Them', Paper presented at Conference for Regulating for a Fair Recovery Network, International Labour Office, Geneva, 6-8 July 2011. ${ }^{146}$ Candland, above n.11, at p. 130.
} 
times even repressive, ${ }^{147}$ of labour and its representative institutions. Yet, on the other hand, there is a plethora of legislation designed to construct a floor of minimum rights underneath the employment relationship across Indian industries and occupations widely. The question is what are we to make of these two apparently mismatched perceptions? It is useful at this point to set out some of this legislative framework in brief detail.

Papola, Pais and Sahu have characterised the minimum rights legislation in India as 'welfare state' inspired; that is to say, that it is designed to protect labour as the weaker party in industrial relations. ${ }^{148}$ The authors group the relevant legislation into four areas - Conditions of Work, Wages and Remuneration, Employment Security, and Social Security. ${ }^{149}$

Among the first set of legislation are included the important provisions of the Factories Act $1948,{ }^{150}$ the Contract Labour (Regulation and Abolition) Act $1970,{ }^{151}$ and the various Shops and Commercial Establishments Acts. ${ }^{152}$ The core purpose of the Factories Act is to ensure the health and safety of workers. It contains specific requirements for factories to be kept clean and sanitary, it regulates hours of work, overtime and annual leave, and provides for mandatory rest days. The Act also makes special provision for women and children regarding their working conditions. One of the key characteristics of Indian labour law is the density of its regulation, and this is exemplified in the terms of the Factories Act. For example the Act specifically prescribes the minimum workspace for each worker, and specifically mandates the manner of cleaning, repainting and so on of regulated premises. ${ }^{153}$ The Act applies to all

\footnotetext{
${ }^{147}$ Particularly during periods of political instability and international conflict: Sundar, above n. 15.

${ }^{148}$ Papola, Pais and Sahu, above n. 93, at p. 15.

${ }^{149}$ This is a slightly amended version of the organisation of legislation presented in the work of Papola, Pais and Sahu, above n. 93. Otherwise, in terms of content our account of the legislation is largely drawn from that of the authors.

${ }^{150}$ Act 63 of 1948 (as amended).

${ }^{151}$ Act 37 of 1970 (as amended by Act 14 of 1986 and Act 4 of 2005).

${ }^{152}$ In addition to these Acts, several others are described by the authors. These include the Interstate Migrant

Workmen (Regulation of Employment and Conditions of Service)Act 1979 (to safeguard the terms and conditions of work of workers engaged by contractors to work in another State; applies across India generally to establishments and/or contractors employing five or more migrant workers); the Mines Act 1952 (to provide mine workers with health and safety protections and other amenities; is limited by numbers of workmen and type of mining undertaken); the Building \& Other Construction Workers (Regulation of Employment and Conditions of Service) Act 1996 (provides for safety, health and welfare measures, as well as regulation of general conditions of work, hours, wages, overtime and so on; is limited in application to establishments of 10 or more workers); and the Beedi \& Cigar Workers (Conditions of Employment) Act 1966 (regulates for workplace facilities, women and young persons in establishments engaged in this specific industry; applies, with few exceptions, to all such establishments across India regardless of size).

${ }^{153}$ See Papola, Pais and Sahu, above n. 93, at p. 23.
} 
manufacturing premises that use electricity and employ 10 or more workers, and to nonpowered premises that employ 20 or more. ${ }^{154}$

The Contract Labour (Regulation and Abolition) Act, as its title suggests, is designed both to prohibit the use of contract labour in certain industries, and to regulate its use in others. Under the terms of the Act the 'appropriate government' (Central or State), pursuant to a prescribed procedure set down in the legislation, may prohibit the employment of contract labour in an industry. In the case of the Central government, the employment of such labour has been prohibited in certain categories of work in mines, on railways and port facilities among others. ${ }^{155}$ The Act otherwise regulates the conditions of work, including payment of wages, hours of work, overtime, leave and so on, in addition to providing various health and safety measures. The Act applies generally across the whole of India, but is limited by size to establishments or contractors employing at least 20 contractors on any day over the previous 12 months. The provisions may also be extended to smaller establishments pursuant to a procedure set down in the legislation.

The Shops and Commercial Establishments Acts are a series of State level enactments designed to supplement the Central government's Factories Act through regulation of shops, restaurants, hotels, places of entertainment such as cinemas, and also small electrical and mechanical repair shops and small manufacturing businesses. Specifically the legislation does not apply to government offices, public utilities such as power and water, and medical centres. The Acts regulate for hours of work, wage rates, overtime, paid holidays, rest days, annual leave, and termination notice, in addition to some health and safety-type provisions. All major States have passed versions of this law, ${ }^{156}$ with sufficient variation between them to enable a ranking of their protective qualities. ${ }^{157}$

\footnotetext{
${ }^{154}$ State governments are permitted to extend the application of this Act to workplaces with a lower threshold number of workers, except in the case of family-based businesses. Whilst some State governments have, from time to time, exercised this power, in general this has not been so as to significantly widen the Act's coverage: see S. Sundar, Current State of Industrial Relations in Tamil Nadu, International Labour Organisation, 2010, at pp. $15,26$.

${ }^{155}$ See Papola, Pais and Sahu, above n. 93, at p. 25. There is some modification to the legislation at State level (see, for example, Andhra Pradesh Act no. 10 of 2002) and other exceptions provided for in the terms of the legislation.

${ }^{156}$ Andaman and Nicobar Islands Shops and Establishments Regulation 2005, Andhra Pradesh Shops and Establishments Act 1988, Assam Shops and Establishments Act 1971, Bihar Shops and Establishment Act 1953, Bombay Shops and Establishments Act 1948 (applies in Gujarat and Maharashtra), Chattisargh Shops and Establishment Act 1958, Goa, Daman and Diu Shops and Establishments Act 1973 (also applies in Dadra and Nagar Haveli), Delhi Shops and Establishments Act 1954, Jammu and Kashmir Shops and Establishments Act 1956, Jharkhand Shops and Establishments Act 1953, Karnataka Shops and Commercial Establishments Act 1961, Kerala Shops and Commercial Establishments Act 1960, Madhya Pradesh Shops and Establishments Act
} 
Two further important pieces of legislation which should be briefly noted here are the Child Labour (Prohibition and Regulation) Act 1986, which abolishes child labour in particular operations and strictly regulates the working conditions where child labour is permitted, and the Bonded Labour System (Abolition) Act 1976 which attempts both to eliminate and rehabilitate bonded labour through strong enforcement mechanisms.

Turning to the matter of 'Wages and Remuneration', four pieces of legislation should be noted. The Minimum Wages Act $1948^{158}$ is a core statute, requiring the appropriate government, whether Central or State, to set minimum wages for certain types of employment or industries as specified in the Schedule to the Act. The legislation applies very widely in terms of numbers of workers covered as there is no minimum limit on the number of employees to be employed for the Act to take effect. However, as is the case with other relevant labour standards, the legislation is limited by reference to those types of employment stipulated in the legislation and the Act's schedule. The schedule lists sectors ranging from carpet making and shawl weaving to various types of mines, plantations, flour mills, tanneries and public motor transport. Coverage is further complicated by many State amendments which both add to and delete from the industries and occupations dealt with. ${ }^{159}$ Rates of pay vary not only from industry to industry, but from State to State, and from region to region. Rural areas generally have lower minimum rates of pay than urban areas. In keeping with the character of Indian labour regulation generally, the determination of minimum rates under the legislation is quite detailed and complex. The minimum standard is set in two parts, a basic rate, plus special allowances to cater for differences in the cost of living.

A second important regulation is the pre-independence Payment of Wages Act $1936{ }^{160}$ This Act was designed to deal primarily with a problem common to Indian industrial relations at the time of its enactment, namely the unauthorised deductions by employers from workers' wages in the form of penalties and fines. Originally the Act was confined to larger

1958, Manipur Shops and Establishments Act 1972, Meghalaya Shops and Establishments Act 2003, Nagaland Shops and Establishments Act 1986, Orissa Shops and Commercial Establishments Act 1956, Pondicherry Shop and Establishment Act 1964, Punjab Shops and Commercial Establishments Act 1958 (also applies in Chandigarh and Haryana), Rajasthan Shops and Commercial Establishments Act 1958, Sikkim Shops and Commercial Establishments Act 1983, Tamil Nadu Shops and Establishments Act 1947, Tripura Shops and Establishments Act 1970, Uttar Pradesh Dookan Aur Vanijya Adhishthan Adhiniyam Act 1962 (which replaced the Uttar Pradesh Shops and Commercial Establishments Act 1947, also applies in Uttarakhand), West Bengal Shops and Establishment Act 1963.

${ }^{157}$ See Dougherty, above n. 119.

${ }^{158}$ Act 11 of 1948 (as amended).

${ }^{159}$ For a complete list of the relevant State amendments see S. Malik and the SCC Editorial Office, P. L. Malik's Industrial Law, Vol II, pp. 2642-2669.

${ }^{160}$ Act 4 of 1936 (as amended). 
establishments in the factories sector and in railways, and, again, only within a certain wage ceiling. However, over time the operation of the Act has been broadened to include other sectors, ${ }^{161}$ although the wage ceiling remains. ${ }^{162}$

Two further wage-related provisions of importance are the Payment of Bonus Act $1965,{ }^{163}$ which provides for the payment of an annual bonus (the amount of which is prescribed in the legislation) to all employees receiving wages below a specified limit. This legislation applies to virtually all States, but is limited to particular establishments employing at least 20 persons. The Equal Remuneration Act $1976^{164}$ prescribes equal remuneration for males and females performing the same work (and other forms of equal treatment), but, again, is limited in application - in this case to establishments which employ 10 or more workers.

The three main sets of regulations providing for various forms of security and welfare benefits are the Employees' State Insurance Act $1948,{ }^{165}$ the Employees' Provident Funds and Miscellaneous Provisions Act 1952, ${ }^{166}$ and the Employees' Compensation Act 1923. ${ }^{167}$ The first of these introduced the Employees' State Insurance Scheme which provides insurance cover for employees in the case of sickness, workplace injury and disablement, and maternity, in addition to death benefits for dependants. The scheme is financed through employer and employee contributions, with medical facilities provided by State governments. Virtually all States are covered by the scheme, but it is limited in application to factories and other establishments (excluding seasonal occupations) employing not less than 20 workers.

The second legislative provision has given rise to three major schemes designed to provide for workers on their retirement or their dependants in cases of early death and so on. Initially the Act set up the Employees' Provident Fund to which it is compulsory for employers and employees to contribute. The scheme is widespread across most States, but is limited by industrial sector and by establishment size (those employing 20 workers or more). It does not apply to government employees, or to workers earning more than a specified amount. Other

\footnotetext{
${ }^{161}$ In the State of Maharashtra, for example, the Act has been extended to all establishments covered under that State's Shops and Commercial Establishments Act: Papola, Pais and Sahu, above n. 93, at p. 31.

162 Presently those workers receiving a wage of more than Rs. 10,000 per month are unable to make use of this legislation to redress wage payment issues arising from their employment.

${ }^{163}$ Act 21 of 1965 (as amended). In form the payment is constituted by what amounts to a 'deferred wage' as well as a form of profit sharing. For discussion on origins and early operation of this Act see: K. Mathur, 'Bonus Legislation in India' (1966) 1 Indian Journal of Industrial Relations 457.

${ }^{164}$ Act 25 of 1976 (as amended).

${ }^{165}$ Act 3 of 1948 (as amended).

${ }^{166}$ Act 19 of 1952 (as amended).

${ }^{167}$ Act 8 of 1923 (as amended). This legislation was formerly the Workmen's Compensation Act 1923: see above n. 25 .
} 
schemes subsequently introduced under this legislation include the Deposit-Linked Insurance Scheme of 1976, and the Employees' Pension Scheme of $1995 .{ }^{168}$

As we noted in Section 2 of this paper, the Employees' Compensation Act 1923, was one of the earliest pieces of labour reform legislation introduced into India in the post-World War One period under the influence of the newly formed International Labour Organisation and was designed with an objective of improving safety standards in industry generally. Under this legislation employers are liable to pay compensation for death or personal injury suffered by employees as a result of a workplace accident or disease arising from employment, unless the accident is directly attributable to the employee's use of alcohol or drugs, disobedience or wilful disregard of safety devices. This legislation applies quite widely both to regular workers, and to those otherwise engaged as part-time, temporary or casual workers, or as contract labour. However, as we have noted, in the unorganised sectors of the economy, and in many cases even in the organised sectors, implementation of this legislation is poor. ${ }^{169}$

Two other pieces of legislation should also be noted. The Maternity Benefit Act 1961 provides both pre-natal and post-natal leave entitlements and wage allowances for female employees. The scheme applies to all establishments covered under the Factories Act, the Mines Act, the Plantations Act, and to some other industries, in addition to all workers covered by the Shops and Commercial Establishments Acts. However it excludes those establishments already covered under the Employees' State Insurance Scheme. The Payment of Gratuity Act 1972 provides for additional payment in the form of a gratuity to employees who have reached the point of taking their superannuation, retirement, resignation or death. The entitlements are limited to employees with continuous service of at least five years, and to establishments employing at least 10 workers.

This brings us finally to the issue of employment security, which, as we noted earlier, is an area of particular controversy in Indian labour market regulation. In this general area the provisions of the Industrial Employment (Standing Orders) Act 1946, and chapters VA and VB of the Industrial Disputes Act in particular, Indian labour law has added a very strong component of protection against and compensation for various forms of dismissal,

\footnotetext{
${ }^{168}$ For details see D. Saini, Social Security Law in India, Kluwer Law International, The Hague, 2011.

${ }^{169}$ See above n. 49 and below n. 186.
} 
retrenchment, and lay-offs, both individual and collective, although these laws are confined to certain types of workers and to certain types of establishments. ${ }^{170}$

Taken at face value this extensive array of labour law suggests a system which is highly protective of labour's interests. It provides a large number of workplace protections, much of which is formally in line with international standards. But at the same time, as we noted above, there has been a longstanding negative response from labour and independent observers about the real value of the labour law system to workers. Making sense of these apparent incongruities self-evidently requires closer analysis.

One avenue of investigation is provided by the data used by scholars exploring the possible link between a country's 'legal origin' and the protective strength of its labour laws. ${ }^{171}$ In this research labour law systems are scored across five sets of variables; the regulation of alternative employment contracts; the regulation of working time; the regulation of dismissal; the regulation of employee representation (including trade union recognition and collective bargaining); and the regulation of industrial action.

Of the five countries examined in the work of Deakin, Lele and Siems, India appears as the third most 'protective' of the labour law systems included ${ }^{172}$ - ranked above the USA and the UK, slightly below the German system and well below the French - and this position largely held true throughout the entire period surveyed (1970-2005). Additional work by a different group of authors using the same coding system and adding two further countries, Australia and New Zealand, to the analysis, shows that India also ranks above those two countries in terms of their protective strengths in labour law, and again that position largely held true throughout the entire period surveyed with the exception of New Zealand from about 1974 until the early 1990s. ${ }^{173}$ Thus of all five common law origin countries represented in the sample, Indian labour law appears most protective, and, importantly, ranks very close to Germany which is generally considered to be among the most labour-friendly of capitalist states. These results would lend some credibility to an argument which proposed that the type

\footnotetext{
${ }^{170}$ See Papola, Pais and Sahu, above n. 93, at pp. 38-42.

${ }^{171}$ S. Deakin, P. Lele and M. Siems, 'The Evolution of Labour Law: Calibrating and Comparing Regulatory Regimes' (2007) 146 Internatioanal Labour Review 133; R. Mitchell, P. Gahan, A. Stewart, S. Cooney and S. Marshall, 'The Evolution of Labour Law in Australia: Measuring the Change' (2010) 23 Australian Journal of Labour Law 61; G. Anderson, P. Gahan, R. Mitchell and A. Stewart, 'The Evolution of Labor Law in New Zealand: A Comparative Study of New Zealand, Australia and Five Other Countries' (2011) 33 Comparative Labor Law and Policy Journal 137.

${ }^{172}$ This is only a small sample of countries: the UK, the USA, France, Germany and India.

${ }^{173}$ Mitchell et al, above n. 171; Anderson et al, above n. 171.
} 
of state socialist policies adopted by the Indian government from the late-1940s onwards, and its 'corporatist' style of economic and labour market regulation was strongly labourprotective. There are, however, several reasons for suggesting that such an assessment, if not entirely incorrect, nevertheless requires a more nuanced interpretation.

First of all, when Indian labour law is looked at comparatively using the same data but at a sub-aggregate level, a very different picture emerges. What we find is that in relation to the forms of contractual arrangements that can be made, and in relation to dismissal in particular, Indian law is very labour protective, ranking above all six other countries surveyed on dismissal, and above all four other common law origin countries surveyed in relation to alternative employment contracts. Viewed largely on the basis of the state of the legal provisions, and in respect of these particular dimensions of labour law, this data does suggest, then, that Indian labour law deserves to be categorised, at least among common law countries, but possibly wider, as highly labour-protective.

The position is, however, quite different once attention is switched to collective labour rights. Particularly in relation to employee representation through trade union recognition, and support for collective bargaining, India now appears at a relatively low level of protection grouped among the common law countries and a long way from the more labour-oriented systems of France and Germany, ${ }^{174}$ although India's relative position vis-a-vis some of the other common law countries has been more volatile throughout the survey period, and certainly has been comparatively strong in relation to the right to take industrial action. ${ }^{175}$

It is possible, of course, that trade unions have been able to exercise influence in the Indian political economy through political and industrial clout, and as we have noted, this has sometimes been a theme in the Indian literature. But the data referred to in the foregoing discussion suggests that if labour has been highly protected vis-a-vis the interests of business it has been through the individual floor of rights constructed by government through legislation rather than through collective rights exercised through trade unions and bargaining, and in this respect the data accords with the views of many authorities. ${ }^{176}$

Other recent 'leximetric' studies of Indian labour law have confirmed this position. In a recent study of the impact of Indian labour law on unemployment, Sarkar has reported that of

\footnotetext{
${ }^{174}$ Deakin, Lele and Siems, above n. 171, at p. 149

${ }^{175}$ Deakin, Lele and Siems, above n. 171; Anderson et al., above n. 171.

${ }^{176}$ See the earlier discussion in Section 2 of this paper.
} 
40 variables used in the Deakin, Lele and Siems study, only nine underwent important variation in the period 1970-2006. Of these nine, eight were associated with improvements in the strength of the law protecting workers in cases of agency labour, individual and collective dismissals, and reinstatement. In other words most labour law change was in the area of individual rights and dismissals. Similarly Dougherty's work using OECD Employment Outlook data records that in respect of both 'regular contracts' and 'collective dismissals' India's Federal-level labour laws were stricter (more onerous on employers) than virtually all OECD countries (as at 2007). ${ }^{177}$

All of this evidence suggests that historically the strategy of the Indian state has been to construct a strong floor of wide-ranging rights for individual workers in their dealings with employers. There remain, however, further matters in debate which continue to call into question both the bona fides and the efficacy of such an approach.

One of the difficulties with the coding method generally employed in the 'leximetric' approach is that it is often difficult to assess the actual impact of the laws studied: generally the law is scored mainly on the basis of its formal qualities, and this was the case with the Deakin, Lele and Siems data for India upon which we have relied in this discussion. ${ }^{178}$ But it is well known that such an approach may produce highly misleading outcomes, and it is important therefore to consider other factors which can be expected to affect the integrity of Indian labour law.

One of these factors concerns the very limited application of the various labour laws of India across the Indian economy generally. ${ }^{179}$ As we have noted in discussion throughout, even much earlier protective provisions applied only in a small proportion of establishments ${ }^{180}$ and this pattern has continued through into most of the modern labour laws. The all important Industrial Disputes Act 1947 applied (and still applies) only to 'workmen' employed in 'industries', and whereas 'industry' has been interpreted reasonably broadly by the Supreme Court, the definition still excludes government employees, agricultural workers and domestic servants. ${ }^{181}$ More than 50 per cent of the Indian workforce was still engaged in the agricultural sector through the 1990s and beyond. ${ }^{182}$ Likewise, the Industrial Employment

\footnotetext{
${ }^{177}$ Dougherty, above n.119.

${ }^{178}$ Deakin, Lele and Siems, above n. 171, at p.150.

${ }^{179}$ Sankaran, above n.14, at pp. 229-235; Damodaran, above n. 136; Bhattacherjee and Ackers, above n. 8.

${ }^{180}$ For example, the Factories Act 1881 applied only to establishments employing at least 100 workers.

${ }^{181}$ Sankaran, above n. 14, at p. 229; see also Gopalakrishnan and Tortell, above n. 49, pp. 532-533.

${ }^{182}$ Government of India, Economic Survey, Ministry of Finance, New Delhi, 2009.
} 
(Standing Orders) Act 1946 applies only to establishments of 100 or more employees, though in some states these provisions have been extended to enterprises employing 50 or more. Many other laws, as we have noted, are limited in application according to size, sector or other criteria. Most industrial workplaces in India simply fall below the threshold employment limit. ${ }^{183}$

Further compromising factors include the structure of the Indian economy generally. The vast majority of Indians are employed on the unorganised (informal) sectors of the economy, ${ }^{184}$ in forms of self-employment, and in casual wage work. As noted above, much of this employment is still rurally based, but in urban areas it includes household workers and servants, and other menial services. ${ }^{185}$ Since the 1990 s there has been a shift in employment away from the organised sectors of the economy to the informal sectors. ${ }^{186}$ There are only 27 million workers employed in the organised private sector of the economy. ${ }^{187}$ Between 1991 and 2006 , there were 870,000 jobs shed from the public sector. ${ }^{188}$ At the same time there has been an increase in the numbers of persons employed as 'contractors' or 'casuals', or where the precise relationship between the worker and the employer is legally uncertain, within the formal sector. Each of these developments inevitably reduces the proportion of the workforce covered by India's labour laws. ${ }^{189}$ Furthermore many workers engaged within the formal sector may still fall beyond the law's protection. According to Sankaran, in 2005 the total workforce of India was 457 million persons, almost 395 million of whom were engaged in

\footnotetext{
${ }^{183}$ Sankaran, above n. 14, at p. 229. To all intents and purposes this means that the small and medium-sized sectors of the economy fall outside the coverage of India's labour laws: Prasad, above n. 89, generally.

${ }^{184}$ As noted earlier (see n. 50) the exact constitution of the 'unorganised' or 'informal' sector is unclear. The definition provided in Prasad, above n. 89, at p. 18, and drawn from the National Accounts Statistics is that it refers to 'all operating units whose activities are not regulated under any statutory Act or legal provision and/or those which do not maintain any regular accounts'. An alternative definition, drawn from the National Commission on Labour (1969), is provided by Singh in the following terms "The unorganised labour ...would be described as those (workers) who have not been able to organise in pursuit of a common objective because of constraints such as: (a) Casual nature of employment, (b) ignorance and illiteracy, (c) small size of establishments per person employed, (d) scattered nature of establishments, and (e) superior strength of the employer operating singly or in combination': M. Singh, 'Unorganised Industries: Conditions of Work and Labour Laws' (1988) 23 Indian Journal of Industrial Relations 373 at p. 373. See also Ratnam, above n. 66, at p. 257.

${ }^{185}$ D'Costa, 'Contemporary Capitalism', above n. 136. See also T. S. Papola, 'Globalisation, Employment and Social Protection: Emerging Perspectives for the Indian Workers' (2004) 47 Indian Journal of Labour Economics 541.

${ }^{186}$ Formal sector employment as a percentage of total employment declined from $7.9 \%$ to $5.8 \%$ between 1983 and 2005: D'Costa, 'Contemporary Capitalism', above n. 136.

${ }^{187}$ D'Costa, 'Contemporary Capitalism', above n. 136, at p. 25.

${ }^{188}$ Government of India, Economic Survey, Ministry of Finance, New Delhi, 2006, 2009.

${ }^{189}$ A provision supporting the extension of social welfare and security schemes to workers in the unorganised sector (The Unorganised Workers' Social Security Act 2008), and other provisions supporting rural employment and job creation have emerged steadily over the past few years, though with mixed effects: see Hill, above n. 15, at pp. 406-407.
} 
the informal sector. Of those in the formal sector only about $53 \%$ were actually covered by the labour laws, the remaining $47 \%$ constituting what amounts to 'informal' employment in the otherwise 'formal' sector. Various figures are advanced, but it is estimated that well over $90 \%$ of the employed workforce falls outside the law's protection. ${ }^{190}$

One further issue concerns the question of enforcement and avoidance. We have noted in earlier discussion that even where the law applies in principle, that is to say in formal terms, it is quite easily ignored or avoided, and thereby its effects are rendered nugatory. There are many different ways in which employers can and do avoid labour regulation, even in the organised sector. ${ }^{191}$ For example firms may avoid retrenchment laws, and health and safety provisions, simply by splitting up large firms into smaller units which are not captured by the legislation, ${ }^{192}$ and through processes of acquisitions and mergers where workers are largely unprotected in practice. ${ }^{193}$ A loophole in the retrenchment laws is the use of voluntary retirement schemes which are often voluntary in name only. ${ }^{194}$ Some businesses simply relocate to areas where enforcement is more lax. ${ }^{195}$ But generally speaking, as we have noted, enforcement is weak everywhere.

It goes without saying that this state of affairs has important implications for the 'protective' profile in Indian labour law. The evidence suggests among other things that most workers do not receive the legislated minimum wage, ${ }^{196}$ and that legislation designed to regulate hours of work, and health and safety and many other conditions are either ignored or not enforced. ${ }^{197}$ Notwithstanding the purpose of the Contract Labour Act, contract labour is rife throughout many of India's most important industries. ${ }^{198}$

All of this suggests that the 'protective' qualities of Indian labour law are largely ineffective when measured across the Indian economy as a whole. Nevertheless this has not interfered with the widespread perception that the overly protective nature of Indian labour law has been

\footnotetext{
${ }^{190}$ See Sankaran, above n.14, at p. 231; Prasad above n. 89, at p. 83. Gopalakrishnan and Tortell, above n. 49, estimate that only about $7 \%$ of the workforce is in the organised sector.

${ }^{191}$ See generally Sundar, above n. 52, at p. 31.

${ }^{192}$ Hill, above n. 15; Warnecke and de Ruyter, above n. 137.

${ }^{193}$ See M. Rajadhyaksha, 'Mergers and Amalgamations in India: Protecting Labour in Times of Change' (2007)

23 International Journal of Comparative Labour Law and Industrial Relations 375; Sundar, above n. 52, at p. 129.

194 Jenkins, above n. 84; Ahsan, Pages and Roy, above n. 85; Sundar, above n. 52, at p. 128.

${ }^{195}$ Warnecke and de Ruyter, above n. 138.

${ }^{196}$ Pais, above n. 140; Sandhu and Sharma, above n.139; Navin, above n. 128.

${ }^{197}$ T. S. Papola, G. S. Mehta and V. Abraham, Labour Regulation and its Impact: A Review of Studies and Documents, Institute for Studies in Industrial Development, New Delhi, 2008; Pais, above n. 140.

${ }^{198}$ See D. S. Saini, 'The Contract Labour Act 1970: Issues and Concerns' (2010) 46 Indian Journal of Industrial Relations 32; Sundar, above n. 52, at pp. 133-136.
} 
a major factor in the evident failure of the Indian formal economy to adapt and develop in the globalised world economy, especially the formal sector. ${ }^{199}$

One major line of investigation has concerned the economic consequences associated with the introduction of the series of amendments to the law during the 1970s and 1980s which, as noted, ${ }^{200}$ provided for stronger employment protections for workers employed in larger firms. In this line of amendments, the introduction in 1976 of Chapter VB into the Industrial Disputes Act 1947, in particular, introduced quite stringent rules against layoffs and retrenchments in firms with $300^{201}$ or more workers. ${ }^{202}$

Early studies, including those by Fallon and Lucas, ${ }^{203}$ Nagaraj, ${ }^{204}$ and Bhalotra, ${ }^{205}$ suggested that these reforms were associated with labour 'hoarding' and reduced labour demand, which in turn hampered employment growth, even while economic growth was accelerating in company with productivity growth. ${ }^{206}$ The study of manufacturing employment by Fallon and Lucas over the period $1959 / 60$ to $1981 / 82,{ }^{207}$ reported that the 1976 amendment was associated with a 17.6 per cent decline in employment across the sectors examined in the study, and that the decline in employment in the larger establishments covered by the provisions had not been associated with a proportionate increase in employment in smaller firms exempted from the law's coverage. ${ }^{208}$ A later study by the same researchers arrived at broadly similar conclusions. ${ }^{209}$ Other studies also attributed negative employment effects to

\footnotetext{
${ }^{199}$ See above n. 84 and associated discussion.

${ }^{200}$ See above nn. 74-77 and associated discussion.

${ }^{201}$ The Act was expanded to cover firms employing 100 or more workers by Act 46 in 1982 .

${ }^{202}$ According to the OECD's measure, the Indian labour law on employment security is more restrictive than all member countries other than Portugal and the Czech Republic: see Dougherty, above n. 119, at p. 303.

${ }^{203}$ P. R. Fallon and R. E. B. Lucas, 'The Impact of Changes in Job Security Regulations in India and Zimbabwe' (1991) 5 The World Bank Economic Review 395; and Fallon and Lucas above n. 94.

${ }^{204}$ R. Nagaraj, 'Employment and Wages in Manufacturing Industries: Trends, Hypotheses and Evidence' (1994) 29 Economic and Political Weekly 177.

${ }^{205}$ S. R. Bhalotra, 'The Puzzle of Jobless Growth in Indian Manufacturing' (1998) 60 Oxford Bulletin of Economics and Statistics 5.

${ }^{206}$ Whilst coming to the same conclusion Ahluwalia explained the slow-down in employment growth as a direct consequence of these same employment security protections on wages growth: see I. J. Ahluwalia, Productivity and Growth in Indian Manufacturing, Oxford University Press, Delhi, 1991.

${ }^{207}$ See Fallon and Lucas (1991), above n. 203.

${ }^{208}$ In subsequent studies, however, some doubt has been cast on these conclusions, particularly insofar as they were based on sub-sector estimates which were shown to be statistically insignificant for the majority of the subsectors included in the analysis: see Bhalotra, above n. 205.

${ }^{209}$ Fallon and Lucas, above n. 94.
} 
the severity of India's employment security laws, albeit through different arguments to those employed in the Fallon and Lucas studies. ${ }^{210}$

Some other studies have sought to examine the economic impact of Indian labour law more broadly. For example, a study by Besley and Burgess ${ }^{211}$ constructed a measure of key State amendments to the Industrial Disputes Act 1947, covering matters such as strikes and lockouts, the adjudication of industrial disputes, closure of firms, layoffs, retrenchments, bargaining and union membership, according to whether they were 'pro-worker' or 'proemployer'. The study drew the conclusion that those Indian States which had introduced 'proworker' reforms had experienced significantly lower levels of growth in output, employment and investment, and had also experienced lower levels of productivity, when compared with States that had not done so. They also found that there were significant increases in employment in the 'unregistered' sector, and increases in urban poverty in those States which had pursued 'pro-worker' reforms. ${ }^{212}$

Although the Besley and Burgess study has come in for some criticism on methodological grounds, ${ }^{213}$ it has nevertheless provided the direction for much subsequent empirical research. This work has confirmed that States with 'pro-employer' legal reforms experienced faster growth in employment and output than did those States with no reforms or with 'pro-worker' reforms. ${ }^{214}$ It also points to the fact that other liberalising reforms, such as de-licensing and tariff reforms, work much more effectively where they are coupled with pro-employer amendments to labour law provisions. ${ }^{215}$ Finally, work by Ahsan and Pages, rather than

\footnotetext{
${ }^{210}$ See S. R. Bhalotra, above n. 205. It should be noted that other research more or less completely discounts the influence of employment security laws on employment growth: see S. D. Roy, above n. 93.

${ }^{211}$ See above n. 83. Here, again, the study is confined to the impact of law in the manufacturing sector of the Indian economy. For similar findings based on a study of the service industry in retailing see M. Ahmin, 'Labor Regulation and Employment in India's Retail Stores' (2009) 37 Journal of Comparative Economics 47.

212 'The results leave little doubt that regulation of labor disputes in India has had quantitatively significant [negative] effects': Besley and Burgess, above n. 84, at p. 124.

${ }^{213}$ See, for example, T. C. A. Anant, R. Hasan, P. Mohapatra, R. Nagaraj and S. K. Sasikumar, 'Labor Markets in India: Issues and Perspectives' in J. Felipe and R. Hasan (eds.), Labor Markets in Asia: Issues and Perspectives, Palgrave Macmillan, Houndmills U.K. and New York, 2006; and A. Bhattacharjea, 'Labour Market Regulation and Industrial Performance in India: A Critical Review of the Empirical Evidence’ (2006) 49 Indian Journal of Labour Economics 211.

${ }^{214}$ See P. Aghion, R. Burgess, S. Redding and F. Zilibotti, 'The Unequal Effects of Liberalization: Theory and Evidence from India' Working Paper No. 12031, National Bureau of Economic Research, Cambridge MA. , 2003.

${ }^{215}$ See, for example, Aghion, Burgess, Redding and Zilibotti, above n. 214, R. Hasan, D. Mitra and K. V. Ramaswamy, 'Trade Reforms, Labor Regulations, and Labor-Demand Elasticities: Empirical Evidence from India' (2007) 89 Review of Economics and Statistics 466; S. K. Bhaumik, S. Gangopadhyay and S. Krishnan, 'Reforms, Entry and Productivity: Some Evidence from the Indian Manufacturing Sector' Working Paper No. 822, William Davidson Institute, University of Michigan, 2006; B. P. Ural and D. Mitra, 'Indian Manufacturing:
} 
aggregating all labour law constraints, has tested for the possibility of a differential impact of employment security and dispute settlement laws. ${ }^{216}$ This research found that reforms in both areas of labour law were associated with negative effects on employment and output. Moreover, the research also showed that where labour law reforms at the State level acted to increase the costs of resolving industrial disputes, this magnified the negative effects of more stringent employment security laws.

Taken as a whole, then, there is considerable evidence in some research to suggest that the perceived rigidities in the Indian labour law system have had, and are continuing to have, negative consequences for the development of the Indian economy. ${ }^{217}$ On the other hand, as we have noted, there are serious doubts on the effectiveness of much of the Indian labour market regulation, even across the formalised sectors of the economy, ${ }^{218}$ and, at the same time, much of the research is limited in scope, and the outcomes subject to question and debate. $^{219}$

\section{The Settlement of Industrial Disputes}

While it seems that the Royal Commission on Labour had anticipated in the 1930s that industrial peace in India would be constructed on the development of strong trade unions and collective bargaining, ${ }^{220}$ this was never an accepted policy direction for Indian employers, who continued trenchantly to resist union recognition and legislation supporting that objective. Amendments to the Trade Unions Act, which provided for a procedure for compulsory recognition, were never given legal effect. ${ }^{221}$ Running parallel with the law on

\footnotetext{
A Slow Sector in a Rapidly Growing Economy' World Bank Policy Research Working Paper No. 4233, World Bank, 2007.

${ }^{216}$ See A. Ahsan and C. Pages, 'Are All Labor Regulations Equal? Evidence from Indian Manufacturing' (2009) 37 Journal of Comparative Economics 62.

${ }^{217}$ One needs to be cautious in interpreting these results in light of other significant shifts in the Indian economy occurring at this time. One authority, for example, points to the puzzling growth in output and productivity despite the decline in employment in manufacturing noted here. This he attributes to patterns of job creation and destruction in the manufacturing sector, as well as wide-ranging reforms that included public sector divestment in manufacturing and the rapid expansion of service industries which by and large have remained outside of the regulatory reach of the Indian labour law system: see Dougherty above n. 119. See also A. Kotwal, B. Ramaswami and W. Wadhwa, 'Economic Liberalization and Indian Economic Growth: What's the Evidence?' (2011) 49 Journal of Economic Literature 1152.

${ }^{218}$ See above nn. 180-199 and associated discussion.

${ }^{219}$ See above nn. 84-94 and associated discussion. See also P. Jha and S. Golder, 'Labour Market Regulation and Economic Performance: A Critical Review of Arguments and Some Plausible Lessons for India' Economic and Labour Market Papers, No. 2008/1, Employment Analysis and Research Unit, Economic and Labour Market Analysis Department, International Labour Office, Geneva, 2008, at pp. 15-20.

${ }^{220}$ Anon., above n.104, at p. 363.

${ }^{221}$ Anon., above n.104; Advani, above n. 62.
} 
trade unions were the laws pertaining to industrial disputes, which began with the Trade Disputes Act 1929, and were followed by the Bombay Trade Disputes (Conciliation) Act 1934, the wartime legislation, and ultimately the Central government's Trade Disputes Act 1947 which consolidated the general governance approach to Indian industrial relations.

The main point of all of this legislation was not, as we noted earlier, to promote industrial peace through collective bargaining. Rather it was an attempt to stifle the development of industrial disputes and their prosecution through strikes and other forms of direct action, firstly by limiting the right to strike, and secondly by empowering government directly, and through its institutions, to seize control of emergent industrial conflict and orient it towards settlement or suppression. Its state powers in this respect were largely unrestricted. We can now turn to look more closely at the detail of these regulations, before attempting to make an assessment of the system's impact on Indian industrial relations.

As we noted in Section 2 of the paper, the Industrial Disputes Act 1947 is the core piece of Central government legislation underpinning the industrial relations system of India. ${ }^{222}$ As is the case with so much of Indian labour law, the Act applies only selectively to particular types of workers, and in particular industries and establishments. ${ }^{223}$ In general terms the Act establishes a multi-tiered industrial dispute resolution system comprising three stages: negotiation, conciliation and adjudication.

A principal objective of the Act, at least in formal terms, is to encourage the resolution of disputes through negotiation between the parties. Most collective agreements entered into between unions and employers arise from conciliated settlements pursuant to s. 12 (3) of the Industrial Disputes Act and are binding upon all of the present and future employees of the employer parties to the settlement including non-union members. Voluntary (i.e. nonconciliated) settlements, on the other hand are binding on only the individual signatories to the particular agreement concerned. ${ }^{224}$ However, the Industrial Disputes Act imposes no legal

\footnotetext{
222 The Industrial Disputes Act 1947 has been amended on a number of occasions (Amending Ordinances of 1948 and 1950, and Acts 54 of 1949, 35 of 1950, 48 of 1950, 65 of 1951, 18 of 1952, 43 of 1953, 48 of 1954,36 of 1956, 41 of 1956, 10 of 1963, 52 of 1963, 18 of 1964, 36 of 1964, 35 of 1965, 57 of 1968, 45 of 1971, 32 of 1972, 45 of 1975, 21 of 1976, 32 of 1982, 49 of 1984, 62 of 1984, 53 of 1987, 39 of 1989, 24 of 1996, Act 53 of 2003, and Act 24 of 2010. It has also been amended by several State level governments - Besley and Burgess, above n. 94, counted 113 State-level amendments as at 2004, and there have been more since. For a full list of current State amendments see the annotations to the Industrial Disputes Act 1947 in Malik, above n. 3, at pp 1997-2169). There is also a large volume of case law dealing with the Act's interpretation (see the many case citations with regard to the Act in Malik, above n. 3, at pp. 1997-2169).

${ }^{223}$ For discussion see Papola, Pais, and Sahu, above n. 93, at pp. 39-42 and pp. 50-53.

${ }^{224}$ Industrial Disputes Act 1947, s. 18(1).
} 
duty upon employers to bargain with trade unions, and as a consequence collective bargaining is not a convention in dispute settlement across Indian industry generally. Various forms of machinery have been introduced into the legislation in attempts to prompt other forms of workplace negotiations or consultations. For example the Act mandates the establishment of Works Committees in workplaces with 100 or more employees. These Committees of 20 members may be comprised of equal numbers of employer and employee representatives or of less employer than employee representatives (there may not be more employer than employee members), and are charged with the duty of promoting and preserving good workplace relations. ${ }^{225}$ A further example is found in the establishment of inhouse machinery for the resolution of individual employment grievances in establishments of 20 or more workers. ${ }^{26}$ Neither the Works Committees, nor the 'Grievance Redressal Machinery', are intended to obstruct the rights of unions to collective bargaining or the rights of individual workers to raise an industrial dispute. ${ }^{227}$

A second approach to dispute settlement in the Industrial Disputes Act includes the processes of conciliation and voluntary arbitration. ${ }^{228}$ Pursuant to the provisions of the Act, the government may appoint Conciliation Officers to mediate in or promote the settlement of industrial disputes in specific areas and industries. ${ }^{229}$ It may also appoint Conciliation Boards. ${ }^{230}$ Where it apprehends that an industrial dispute exists, the Appropriate Government may refer such dispute to a Conciliation Board. Alternatively, the parties to a dispute may apply jointly or separately for a reference to a Board, and if the government is satisfied that the disputants represent a majority of each party it is under an obligation to make the reference accordingly. ${ }^{231}$ There is also scope under the Act for the parties voluntarily to refer the dispute to arbitration. ${ }^{232}$

In the case of collective disputes there is no automatic path in the conciliation process to a supervised settlement. The Conciliation Officer or Board may settle the dispute, but in the

\footnotetext{
${ }^{225}$ Industrial Disputes Act 1947, s. 3.

${ }^{226}$ See Chapter II-B of the Industrial Disputes Act (s. 9C), introduced in 2010.

${ }^{227}$ The term 'industrial dispute' is defined quite widely under the Act as 'any dispute or difference between employers and employers, between employers and workmen or between workmen and workmen'. It also includes a dispute over dismissal from employment. See: Industrial Disputes Act 1947, s. 2(k).

${ }^{228}$ Compulsory processes apply in the case of disputes in public utilities: see Industrial Disputes Act 1947 ss. 10,12 and 22.

${ }^{229}$ Industrial Disputes Act 1947, s. 4.

${ }^{230}$ Industrial Disputes Act 1947, s. 5. It should be noted, however, that in practice this provision is virtually defunct; no such Boards have been created for the best part of 40 years.

${ }^{231}$ Industrial Disputes Act 1947, s. 10(2).

${ }^{232}$ Industrial Disputes Act 1947, s. 10A (inserted by Act 36 of 1956).
} 
event that it cannot do so it must send a 'failure' report to the government. The government retains the discretion to decide if the case should be referred to a Labour Court or Tribunal for adjudication. Strict limitations apply to the taking of industrial action while these processes are in train. ${ }^{233}$

The Act also provides for the government to establish Labour Courts and Industrial Tribunals $^{234}$ for dealing with industrial disputes, ${ }^{235}$ and for it to constitute Courts of Inquiry 'for inquiring into any matter appearing to be connected with or relevant to an industrial dispute'. ${ }^{236}$ As we have noted, generally speaking the government has a controlling discretion in relation to these matters. In the event of a failure to settle the dispute through the conciliation stage, the government may refer the dispute to a court or a tribunal. Alternatively the parties to a dispute may apply to the government jointly or separately for a reference of a dispute to a court or tribunal, and, as is the case with the conciliation process, if the government is satisfied that the persons applying represent the majority of each party, it must make the reference accordingly. ${ }^{237}$ The government is not required under the legislation to give the parties any hearing when exercising its discretion either to refer or not to refer a dispute to a court or tribunal. One major exception to the government's discretion on adjudication concerns the dismissal or retrenchment of individual workers. In such cases a 2010 amendment has provided workers with direct access to a Labour Court or Industrial Tribunal without the requirement of a government reference. ${ }^{238}$ Once again, the various

\footnotetext{
${ }^{233}$ This includes a general prohibition on strikes and lockouts: see s. 23 of the Act.

${ }^{234}$ There is scope in the Act for the creation of Industrial Tribunal and National Tribunals. National Tribunals are specifically designated for dealing with industrial disputes 'which, in the opinion of the Central Government, involve questions of national importance or are of such a nature that industrial establishments situated in more than one State are likely to be interested in, or affected by, such disputes': Industrial Disputes Act 1947, s. 7$\mathrm{B}(1)$.

${ }^{235}$ Disputes are divided between Labour Courts and Industrial Tribunals according to the Schedules to the Act. Pursuant to the Second Schedule Labour Courts may deal with matters concerning the legality or propriety of orders passed by an employer under its standing orders; the discharge and dismissal of workers, and the illegality or otherwise of strikes and lockouts among other things. Labour Courts also have jurisdiction over matters set down in the Third Schedule. The jurisdiction of the Industrial Tribunals pursuant to the Third Schedule is confined to disputes over wages, compensation and other allowances, hours of work, leave, rules of discipline, retrenchment of workers and closure of the enterprise among other matters.

${ }^{236}$ Industrial Disputes Act 1947, ss. 6, 7, 7A and 7B.

${ }^{237}$ Industrial Disputes Act 1947, s. 10(2).

${ }^{238}$ Industrial Disputes Act 1947, s. 2-A (2) (inserted by Act 24 of 2010). Some earlier State amendments had similar effect, permitting an individual worker to apply directly to a Labour Court in the case of a dispute over dismissal, either following the failure of conciliation (Tamil Nadu Act no. 5 of 1988; Andhra Pradesh Act no. 32 of 1987) or directly on the existence of the dispute (Karnataka Act no. 5 of 1988; Delhi Act no. 9 of 2003).
} 
processes of adjudication under the Act are accompanied by strict limitations on the rights of all parties to engage in industrial action. ${ }^{239}$

If, as we have noted in earlier discussion, Indian labour law is not effectively 'protective' of Indian labour, the question remains whether it has been more successful in the second of its core objectives; i.e. in facilitating the efficient settlement of industrial disputes and thus constraining the level of industrial action in the day-to-day affairs of Indian industrial relations?

Viewed over its lengthy period of operation, Indian labour law does not appear to have been very successful in engineering industrial peace. While India's law does not prohibit industrial action per se, the strongly interventionist role of the state, coupled with the highly restrictive and uncertain ${ }^{240}$ nature of the law on strikes has given rise to a perception that it is a disordered, disruptive and heavily politicised dispute settlement process, ${ }^{241}$ with strong negative implications for the Indian economy. ${ }^{242}$ Thus scholars have noted the comparatively high number of working days lost through strikes in India, ${ }^{243}$ the levels of union militancy generally, ${ }^{244}$ and the general failure of the dispute settlement mechanisms and other legal processes to resolve these problems. ${ }^{245}$ While there has been a general decline in the numbers of disputes and strikes in recent decades, ${ }^{246}$ and a consequent decline in the numbers of

\footnotetext{
${ }^{239}$ Industrial Disputes Act 1947, ss. 22 and 23.

${ }^{240}$ Or 'ambiguous': see Bhattacharjee and Ackers, above n. 8, at p. 112.

${ }^{241}$ See generally, B. P. Rath and B. B. Das, 'Right to Strike: An Analysis' (2005) 41 Indian Journal of Industrial Relations 248; A. K. Sen Gupta and P. K. Sett, 'Industrial Relations Law, Employment Security and Collective Bargaining in India: Myths, Realities and Hopes' (2000) 31 Industrial Relations Journal 144; S. Kuruvilla, 'Linkages Between Industrialization Strategies and Industrial Relations/Human Resource Policies: Singapore, Malaysia, the Philippines and India' (1998) 49 Industrial and Labor Relations Review 635; Sodhi, above n. 96, at pp. 45-46; E. A. Ramaswamy, 'Indian Management Dilemma: Economic Versus Political Unions' (1983) 23 Asian Survey 976.

${ }^{242}$ For example, in their recent study of Indian manufacturing industries, Ahsan and Pages noted several poor outcomes arising from the industrial dispute resolution legislation including the negative impact of the costs of dispute settlement on investment, output, employment and wages in particular: see Ahsan and Pages, above n. 216.

${ }^{243}$ See Kuruvilla, above n. 241, at p. 650; Ahsan and Pages, above n. 216, at p. 63; S. Nath, 'Labour Policy and Economic Reforms in India' in B. Debroy and P. D. Kaushik (eds.), above n. 53, at pp. 174-178.

${ }^{244}$ E. M. Rao, 'The Rise and Fall of Indian Trade Unions: A Legislative and Judicial Perspective' (2007) 42 Indian Journal of Industrial Relations 678.

${ }^{245}$ Illegal strikes, for example, are rarely ever prosecuted: Nath, above n. 243, at p. 189.

${ }^{246}$ See Candland, above n. 11 at p. 31; A. U. Khan, 'Regulating Labour Markets' in Debroy and Kaushik (eds.), above n. 53, at p. 78 .
} 
working days lost due to such action, the impact of this has to a considerable degree been offset by a corresponding increase in the numbers of employer lockouts. ${ }^{247}$

Much of the focus in the literature points to administrative weaknesses in the adjudication system described earlier. ${ }^{248}$ One major concern is the sheer volume of disputes to be dealt with by the labour courts and tribunals, which leads to inordinate delays at both the referral and settlement stages of the conciliation and adjudicative process. ${ }^{249}$ A second problem concerns the potential for misuse of the dispute settlement mechanisms. Some scholars have argued that the subjective nature of the referral powers in the legislation has created the conditions through which they may be used for political and other extraneous (or corrupt) purposes, and that in fact such practices do take place, resulting in unjust outcomes for unions and labour in particular. ${ }^{250}$ One obvious consequence of this is that the number of collective interest disputes coming into the adjudication system has declined substantially in the past two decades as workers tend to accept what the employer has to offer rather than risk taking direct action. ${ }^{251}$ Taken as a whole, then, the weight of evidence suggests that the dispute settlement process in Indian labour law engenders industrial conflict rather than promotes industrial peace, ${ }^{252}$ or at least secures labour compliance under highly unfavourable terms.

One final point to note in this discussion of dispute settlement is the impact that the Indian labour law system has had upon the Indian trade union movement. As we have noted at various points throughout this paper, trade unions have not been as strongly legally incorporated into the regulatory system as in many other countries, and as a consequence their influence through collective bargaining and through the various other dispute settlement mechanisms has been comparatively muted. One illustrative example of this is found in the impact that the delays and costs associated with the disputes referral system has had in cases

\footnotetext{
${ }^{247}$ See Kuruvilla, above n. 241, at pp. 651-652; Reddy, above n. 113, at p. 69; D. Banerjee, Labour Regulation and Industrial Development in West Bengal, Institute for Studies in Industrial Development, New Delhi, 2008, at pp. 71-76.

${ }^{248}$ See above nn. 208-218 and associated discussion.

${ }^{249}$ For example, according to one study, proceedings in labour courts are on average ten years in duration: see A. Ahsan, 'Labour Regulations in India: Impact and Policy Reform Options', World Bank, New Delhi, 2006. See also Penfold, above n. 114.

${ }^{250}$ See D. S. Saini, 'Reference Power of State in Industrial Dispute Adjudication: A Study with Reference to Industrial Disputes in Faridabad' (1993) 35 Journal of the Indian Law Institute 233; D. S. Saini, 'Labour Courts Administration in India' in Labour Adjudication in India, International Labour Organisation, New Delhi, 1997; Gopalakrishnan and Tortell, above n. 49.

251 See Saini 1993 and 1997, above n. 250.

${ }^{252}$ See the references in nn. 241 to 251 above; and see further, Kaul, above n. 61; S. P. S. Ahluwalia, 'Legislative Framework: Need for Relook' (1990) 25 Indian Journal of Industrial Relations 380; D.S. Saini, 'Compulsory Adjudication of Industrial Disputes: Juridification of Industrial Relations' (1991) 27 Indian Journal of Industrial Relations 1; Sodhi, above n. 95.
} 
of anti-union victimisation and discrimination by employers. ${ }^{253}$ Perhaps as a consequence of this legal disadvantage, in industrial terms unions are very weak. They are also marked by very low membership, ${ }^{254}$ multiplicity, fragmentation, rivalry, ${ }^{255}$ and are intensely politicised $^{256}$ partly as a result of provisions of the Trade Unions Act 1926 which permit executive members of trade unions to be drawn from external, politically allied, bodies. As a result, most of the power of Indian trade unions, which recently has been in decline, ${ }^{257}$ has been derived from their connections with political parties and policies. At the same time, this has made them vulnerable to political appropriation. ${ }^{258}$

\section{Conclusion}

Thinking about labour law in India requires us to think not merely about the application of a set of legal or regulatory conventions governing labour in a particular society. It also requires us to think about what 'labour law' might mean in varying economic and social contexts. In certain respects Indian labour law is much like the labour law of developed industrial societies. It has extensive legislation providing for minimum standards of employment, social security, occupational health and safety and so on. Its labour law legalises trade unions and their activities, and provides a framework for the settlement of industrial disputes. It legalises industrial action in pursuit of collective interests. Yet, as we have seen, formally the labour law of India covers only a very small percentage of the Indian workforce, and even among that cohort the law's application in practice is lax to say the least. Neither of the two principal objects of the labour law system identified in this paper appears to have been met in practice. To all intents and purposes then, this is a non-functioning system.

If we were to adopt a fairly conventional approach to labour law, i.e. if we were to confine our inquiry to the usual parameters of labour law subject matter, it would follow that our

\footnotetext{
${ }^{253}$ See D. S. Saini, 'Dynamics of New Industrial Relations and Postulates of Industrial Justice’ (2003) 46 Indian Journal of Labour Economics 651; Gopalakrishnan and Tortell, above n. 49.

254 'Barely 2 per cent of the total workforce in India is unionised': Gopalakrishnan and Tortell, above n. 49, at p. 531.

${ }^{255}$ Ahluwalia, above n. 251; Gopalakrishnan and Tortell, above n. 49, at p. 531.

${ }^{256}$ B. Singh, 'Global Crisis and Response of Labour Unity to Enforce Decent Working Conditions', Paper prepared for the conference Regulating for a Fair Recovery, International Labour Office, Geneva, 2011, at pp. 7-8; Kuruvilla, above n. 241, at p. 650; Cooke, above n. 85, at p. 192; Advani, above n.61; Bhattacherjea and Ackers, above n. 8, at p. 109; Penfold, above n. 114, at p. 98; Mathur, above n. 56, at p. 167.

${ }^{257}$ Jenkins, above n. 84, at p. 50, Gupta and Sett, above n. 241, pp. 149-150.

${ }^{258}$ Advani, above n. 61, at p. 35 and n. 73 at that page.
} 
investigation would extend to a number of consequent questions and issues. These might include an examination of the limited coverage of Indian labour law amongst classes of workers, business establishments and particular occupations, and the reasons for those limitations; the weaknesses and failings of the enforcement system; and how to extend the idea of labour law to what are labelled 'precarious', 'marginal' or 'atypical' labour.

However, in our opinion such an approach would fail to deal adequately with the problems identified. India is a 'quasi'-industrialised society. It has a rapidly growing economy, but it is not industrialising in a way that might have been anticipated following independence. ${ }^{259}$ If there is to be an ongoing international and comparative discussion in labour law, particularly one involving major nations such as China, India and Indonesia and so on, we cannot shape the discussion about labour law in so confined a manner. We cannot assume that developing countries will necessarily industrialise in ways similar to the pattern set by earlier developers. ${ }^{260}$ Some further line of investigation by labour lawyers is needed in order to discover what truly is 'regulating' 'labour' in India.

One such line of inquiry is suggested in the form of the novel social protection initiatives being introduced in India. These include the Mahatma Ghandi National Rural Employment Guarantee Scheme which is designed to provide a minimum income through a right to work guarantee to the very poor, ${ }^{261}$ and the Unorganized Sector Workers' Social Security Bill 2008 which is designed, eventually, to extend a social welfare network of schemes embodying life and disability cover, health and maternity benefits, old age protection and so on to the 60 million or so workers in the unorganised sectors of the economy and their families. These kinds of laws and regulations are not typically part of labour law discourse; they tend to be included at the margins, if at all. Yet, the study of labour law in India suggests that we should be looking at a multi-faceted approach to labour regulation. Where formal or conventional ideas of labour law are ineffective or irrelevant, something else is relevant to labour's condition. In India that includes the extensive influence of custom, caste, religion and class in determining the rights of labour and the protections extended to it. This suggests that a new approach is warranted.

\footnotetext{
${ }^{259}$ See C. K. Johri, 'Industrialism and Industrial Relations in India: The Task Ahead' (1990) 25 Indian Journal of Industrial Relations 230.

${ }^{260}$ Furthermore, although it is not immediately germane to our present discussion, it cannot be assumed that presently developed nations will continue to be industrialised in the same way in the future. This issue has general implications for the regulation of labour markets everywhere.

${ }^{261}$ This legislative scheme was originally introduced in the form of the National Rural Guarantee Act 2005, but was renamed in 2009 .
} 


\section{BIBLIOGRAPHY}

\section{Books and Reports}

I. J. Ahluwalia, Productivity and Growth in Indian Manufacturing, Oxford University Press, Delhi, 1991.

A. Ahsan, 'Labour Regulations in India: Impact and Policy Reform Options', World Bank, New Delhi, 2006.

A. Amjad, Labour Legislation and Trade Unions in India and Pakistan, Oxford University Press, Oxford, 2001.

D. Banerjee, Labour Regulation and Industrial Development in West Bengal, Institute for Studies in Industrial Development, New Delhi, 2008.

N. Bose, Indian Labour Code, Eastern Law House, Calcutta, 1950.

C. Candland, Labor, Democratization and Development in India and Pakistan, Routledge, London, 2007.

S. Cooney, T. Lindsey, R. Mitchell and Y. Zhu (eds.), Law and Labour Market Regulation in East Asia, Routledge, London, 2002.

G. Davidov and B. Langille (eds.), The Idea of Labour Law, Oxford University Press, Oxford, 2011.

P. Garibaldi, A.V. Jose and K.R. Shyam Sundar, Labour Regulation, Labour Flexibility and Labour Reforms in Europe: Some Perspectives with Possible Lessons for India, Institute for Studies in Industrial Development, New Delhi, 2008.

Government of India, Economic Survey, Ministry of Finance, New Delhi, 2006 and 2009.

International Labour Organization, Organization, Bargaining and Dialogue for Development in a Globalizing World, Governing Body, $279^{\text {th }}$ Session, Geneva, 2000.

G. M. Kothari and A. G. Kothari, A Study of Industrial Law, Vols. 1 and 2, N. M. Tripathi Private Limited, Bombay, $4^{\text {th }}$ edition, 1987.

Labour Bureau, India Labour Year Book, Ministry of Labour and Employment, Government of India, New Delhi, 2004.

S. Malik, P. L. Malik's Industrial Law, Vols. I and II, Eastern Book Co., Lucknow, 23rd edition, 2011

A. S. Mathur, Labour Policy and Industrial Relations in India, Ram Prasad and Sons, Agra, 1968. 
S. Mishra, Modern Labour Laws and Industrial Relations, Deep and Deep Publications, New Delhi, 1992.

S.N. Mishra, Labour and Industrial Laws, Central Law Publications, Allahabad, $26^{\text {th }}$ edition, 2011.

C. Myers, Labor Problems in the Industrialization of India, Harvard University Press, Cambridge Massachusetts, 1958.

P. Nicholson and S. Biddulph (eds.), Examining Practice, Interrogating Theory:

Comparative Legal Studies in Asia, Brill, Leiden, 2008.

OECD, Economic Policy Reforms: Going for Growth 2010. Structural Policy: Indicators, Priorities and Analysis. OECD, 2010.

O. Ornati, Jobs and Workers in India, Institute of International Industrial and Labor Relations, Cornell University, Ithaca NY, 1955.

G. P. Pai, Labour Law in India, Butterworth, New Delhi, 2001.

J. Pais, Effectiveness of Labour Regulations in Indian Industry, Institute for Studies in Industrial Development, New Delhi, 2008.

T. S. Papola, G. S. Mehta and V. Abraham, Labour Regulation and its Impact: A Review of Studies and Documents, Institute for Studies in Industrial Development, New Delhi, 2008.

T. S. Papola, J. Pais and P. P. Sahu, Labour Regulation in Indian Industry: Toward an Equitable Framework, Institute for Studies in Industrial Development, New Delhi, 2008.

V. N. Prasad, Labour Regulation in Small Enterprises: Coverage and Impact, Institute for Studies in Industrial Development, New Delhi, 2008.

E. A. Ramaswamy, Power and State, Oxford University Press, New Delhi, 1984.

C. S. Venkata Ratnam (ed.), Industrial Relations in Indian States, Indian Industrial Relations Association/Global Business Press, New Delhi, 1996.

D. N. Reddy, Labour Regulation, Industrial Growth and Employment: A Study of Recent Trends in Andhra Pradesh, Institute for Studies in Industrial Development, New Delhi, 2008.

P. Robb, Peasants, Political Economy, and Law, Oxford University Press, New Delhi, 2007.

T. Roy, Rethinking Economic Change in India, Routledge, London, 2005.

D. Saini, Social Security Law in India, Kluwer Law International, The Hague, 2011.

S. K. Sen, Working Class Movements in India, 1885-1975, Oxford University Press, New Delhi, 1994. 
S. Sen and B. Dasgupta, Unfreedom and Waged Work: Labour in India's Manufacturing Industry, Sage Publications, New Delhi, 2009.

A. N. Sharma and V. Kalpana, Labour Regulation and Industrial Development in Uttar Pradesh: Some Recent Trends, Institute for Studies in Industrial Development, New Delhi, 2008.

K. R. Shyam Sundar, Impact of Labour Regulations on Industrial Development and Employment: A Study of Maharashtra, Institute for Studies in Industrial Development, New Delhi, 2008.

K. R. Shyam Sundar, Current State and Evolution of Industrial Relations in Maharashtra, International Labour Organization, Geneva, 2009.

K. R. Shyam Sundar, Current State and Evolution of Industrial Relations in Tamil Nadu, International Labour Organization, Geneva, 2010.

C. P. Thakur, Labour Policy and Legal Framework in India: A Review, Institute for Studies in Industrial Development, New Delhi, 2008.

K. N. Vaid, State and Labour in India, Asian Publishing House, London, 1965.

\section{Chapters in Books}

A. Ahsan, C. Pages and T. Roy, 'Legislation, Enforcement and Adjudication in Indian Labor Markets' in D. Mazumdar and S. Sarkar (eds.), Globalization, Labour Markets and Inequality in India, International Development Research Centre, Ottawa, 2008.

T Anant, R. Hasan, P. Mohopatra, R. Nagaraj and S. Sasikumar, 'Labour Markets in India: Issues and Perspectives' in J. Felipe and R. Hasan (eds.), Labour Markets in India: Issues and Perspectives, Palgrave Macmillan, Basingstoke, 2006.

M. R. Anderson, 'Work Construed: Ideological Origins of Labour Law in British India to 1918 ' in P. Robb (ed.), Dalit Movements and the Meaning of Labour in India, Oxford University Press, Delhi, 1993.

F. L. Cooke, 'Employment Relations in China and India' in M. Barry and A. Wilkinson (eds.), Research Handbook of Comparative Employment Relations, Edward Elgar, Cheltenham UK, 2011.

N. Crook, 'Labour and the Steel Towns' in P. Robb (ed.), Dalit Movements and the Meaning of Labour in India, Oxford University Press, Delhi, 1993.

B. Debroy, 'Issues in Labour Law Reform' in B. Debroy and P. D. Kaushik (eds.), Reforming the Labour Market, Academic Foundation, New Delhi, 2005. 
V. DeSousa, 'Colonialism and Industrial Relations in India' in S. Kuruvilla and B. Mundell (eds.), Colonialism, Nationalism and the Institutionalization of Industrial Relations in the Third World, JAI Press, 1999.

S. Ghose, 'Alternative Dispute Settlement Mechanisms in India - A Study of Industrial Adjudication' in A. Sivanthiran and C. S. Venkata Ratnam (eds.), Prevention and Settlement of Disputes in India, International Labour Organisation, New Delhi, 2003.

R. Gopalakrishnan, 'Enforcing Labour Rights Through Human Rights Norms: The Approach of the Supreme Court of India' in C. Fenwick and T. Novitz (eds.), Human Rights at work: Perspectives on Law and Regulation, Hart Publishing, Oxford and Portland, Oregon, 2010.

A. K. Hazra, 'Labour Laws and Industrial Relations' in B. Debroy and P. D. Kaushik (eds.), Reforming the Labour Market, Academic Foundation, New Delhi, 2005.

C.K. Johri, 'India' in R. Blanpain (ed.) International Encyclopaedia for Labour Law and Industrial Relations, Kluwer Law International, Alphen aan den Rijn, Netherlands, Supplement 262, December 2002.

B. T. Kaul, 'Pitfalls in the Industrial Relations Law in India' in S. N. Singh (ed.), Law and Social Change: Essays on Labour Law and Welfare Research Methodology and Environmental Protection, G. Krishnan Memorial Foundation, Delhi, 1990.

A. U. Khan, 'Regulating Labour Markets' in B. Debroy and P. D. Kaushik (eds.), Reforming the Labour Market, Academic Foundation, New Delhi, 2005.

D. S. Leelavathi, 'The Contours of Labour Sector Reforms in India' in G. Saibaba, G. Erraiah, M. Devarajulu and M. Chinnaswamy Naidu (eds.), Labour and Development in Twenty First Century, Serials Publications, New Delhi, 2005.

D. McCann, 'The Regulation of Working Conditions in Asia and the Pacific: Flexibility, Fragmentation and Worker's Rights' in S. Lee and F. Eyraud (eds.), Globalization,

Flexibilization and Working Conditions in Asia and the Pacific, International Labour Office and Chandos Publishing, Geneva and Oxford, 2008,

R. Mohan, 'Industrial Policy and Controls' in B. Jalan (ed.), The Indian Economy: Problems and Prospects, Penguin, New Delhi, 2004.

S. Nath, 'Labour Policy and Economic Reforms in India' in B. Debroy and P. D. Kaushik (eds.), Reforming the Labour Market, Academic Foundation, New Delhi, 2005.

A. Prakash, 'The Purpose and Future Direction of Industrial Disputes Legislation in India' in

C. K. Johri (ed.), Issues in Indian Labour Policy, Shri Ram centre for Industrial Relations, New Delhi, 1969.

T. Roy, 'Law and Economic Change in India, 1600-1900' in D. Ma and J. L. Van Zanden (eds.), Law and Long Term Economic Change: A Eurasian Perspective, Stanford University Press, Stanford California, 2011. 
D. S. Saini, 'Labour Courts Administration in India' in Labour Adjudication in India, International Labour Organisation, New Delhi, 1997

K. Sankaran, 'Labour Law in South Asia: The Need for an Inclusive Approach' in T. Tekle (ed.), Labour Law and Worker Protection in Developing Countries, International Labour Office/Hart Publishing, Oxford and Geneva, 2010.

C. S. Venkata Ratnam, 'Economic Liberalization and the Transformation of Industrial Relations Policies in India' in A. Verma, T. A. Kochan and R. D. Lansbury (eds.), Employment Relations in the Growing Asian Economies, Routledge, London and New York, 1995.

J. G. Scoville, M. Toha and S. Tripathi, 'Ethnicity, Caste, Religion and Occupational Structure in Traditional Activities: A Preliminary View from North India' in J. G. Scoville (ed.), Status Influences in Third World Labor Markets, Walter de Gruyter, Berlin, 1991.

J. J. Thomas, 'An Uneasy Coexistence: The New and the Old in Indian Industry and Services' in A. P. D’Costa (ed.), A New India? Critical Reflections in the Long Twentieth Century, Anthem Press, London, 2010.

S. Thorat and K. S. Newman, 'Introduction - Economic Discrimination: Concept, Consequences and Remedies' in S. Thorat and K. S. Newman (eds.) Blocked by Caste: Economic Discrimination in Modern India, Oxford University Press, New Delhi, 2010.

\section{Journal Articles and Papers}

G. M. Advani, 'State Intervention in Labour Relations: Canada and India' (1961) 19 Faculty of Law Review (University of Toronto) 23.

P. Aghion, R. Burgess, S. Redding and F. Zilibotti, 'The Unequal Effects of Liberalization: Evidence from Dismantling the License Raj in India', Working Paper 12031, National Bureau of Economic Research, Cambridge Massachusetts, 2006.

S.P.S. Ahluwalia, 'Legislative Framework: Need for Relook' (1990) 25 Indian Journal of Industrial Relations 380.

A. Ahsan and C. Pages, 'Are All Labor Regulations Equal? Evidence from Indian Manufacturing' (2009) 37 Journal of Comparative Economics 62.

A. Amin, 'Labor Regulation and Employment in India's Retail Stores' (2009) 37 Journal of Comparative Economics 47.

G. Anderson, P. Gahan, R. Mitchell and A. Stewart, 'The Evolution of Labor Law in New Zealand: A Comparative Study of New Zealand, Australia and Five Other Countries' (2011) 33 Comparative Labor Law and Policy Journal 137. 
Anon. 'Wartime Developments in Trade Union Organisation in India' (1946) 53

International Labour Review 349.

Anon. 'A Decade of Labour Legislation in India, 1937-1948:II' (1949) 59 International Labour Review 506.

B. Banerjee and J. B. Knight, 'Caste Discrimination in the Indian Urban Labour Market' (1985) 17 Journal of Development Economics 277.

S.R. Bhalotra, 'The Puzzle of Jobless Growth in Indian Manufacturing' (1998) 60 Oxford Bulletin of Economics and Statistics 5.

A. Bhattacharjea, 'Labour Market Regulation and Industrial Performance in India: A Critical Review of the Empirical Evidence' (2006) 49 Indian Journal of Labour Economics 211.

D. Bhattacherjee, 'Organized Labour and Economic Liberalization in India: Past Present and Future', Indian Institute of Management, Discussion Paper 105, Calcutta, 1999.

D. Bhattacherjee and P. Ackers, 'Introduction: Employment Relations in India - Old Narratives and New Perspectives' (2010) 41 Industrial Relations Journal 104.

S.K. Bhaumik, S. Gangopadhyay and S. Krishnan, 'Reforms, Entry and Productivity: Some Evidence from the Indian Manufacturing Sector', Working Paper no. 822, William Davidson Institute, University of Michigan, 2006.

T. Besley and R. Burgess, 'Can Labor Regulation Hinder Economic Performance? Evidence from India’ (2004) 119 Quarterly Journal of Economics 91.

Sir A. C. Chatterjee, 'Federalism and Labour Legislation in India' (1944) 49 International Labour Review 415.

S. Damodaran, 'New Challenges to Regulation, the Record of Violations and the Responses in Globalised Labour Markets: The Indian Case', paper prepared for Conference on Regulating for a Fair Recovery Network, International Labour Office, Geneva, 6-8 July 2011.

S. Damodaran, 'Global Production, Employment Conditions and Decent Work: Evidence from India's Informal Sector', paper prepared for Conference on Decent Work, International Labour Office, Geneva, 2009.

A. Das and D. Pandey, 'Contract Workers in India: Emerging Economic and Social Issues' (2004) 40 Indian Journal of Industrial Relations 242.

R. K. Das, 'Labour Legislation in India' (1930) 22 International Labour Review 599.

R. K. Das, 'Labour Legislation in Indian States' (1938) 38 International Labour Review 794.

M. B. Das and P. V. Dutta, 'Does Caste Matter for Wages in the Indian Labor Market?' Social Development Unit, World Bank, 2007. 
R. Datt, 'Regional Patterns of Industrial Relations in India: Changing Scenario after Liberalisation' (2000) 43 Indian Journal of Labour Economics 1061.

R. Datt, 'National Commission on Labour and Review of Labour Laws' (2003) 46 Indian Journal of Labour Economics 109.

I. Dayal, 'Constraints of Legislation on Organisational Effectiveness' (1967) 2 Indian Journal of Industrial Relations 315.

A. P. D'Costa, 'Geography, Uneven Development and Distributive Justice: The Political Economy of IT Growth in India' (2011) 4 Cambridge Journal of Regions, Economy and Society 237.

A. P. D'Costa 'Contemporary Capitalism and the Challenges for Inclusive Development in India', paper presented at the Inclusive Growth in China and India: Role of Institution Building and Governance Workshop, School of Economics, University of Sydney, 2011.

S. Deakin, P. Lele and M. Siems, 'The Evolution of Labour Law: Calibrating and Comparing Regulatory Regimes’ (2007) 146 International Labour Review 133.

T. Deb, 'Reforming Labour Legislation on Working Conditions for Competitive Advantage: An Empirical Study’ (2010) 46 Indian Journal of Industrial Relations 201.

S. M. Dougherty, "Labour Regulation and Employment Dynamics at the State Level in India’ (2009) 1 Review of Market Integration 295.

P. R. Fallon and R.E.B Lucas, 'The Impact of Changes in Job Security Regulations in India and Zimbabwe' (1991) 5 The World Bank Economic Review 395.

P. Fallon and R. Lucas, 'Job Security Regulations and the Dynamic Demand for Labour in India and Zimbabwe' (1993) 40 Journal of Development Economics 241.

J. Folkerth and T. Warnecke, 'Organising Informal Labor in India and Indonesia: A Discussion of Barriers and Best Practices of Overcoming Them', paper prepared for the conference Regulating for a Fair Recovery Network, International Labour Office, Geneva, 68 July 2011.

R. Gopalakrishnan and L. Tortell, 'Access to Justice, Trade Union Rights, and the Indian Industrial Disputes Act, 1947' (2006) 22 International Journal of Comparative Labour Law and Industrial Relations 529.

N. C. F. Gupta, 'Increasing Inequalities in the Context of Growth: Findings from Two Industrial Areas in India', paper prepared for the conference Regulating for Decent Work: Regulating for a Fair Recovery, International Labour Office, Geneva, 2011.

A. K. Sen Gupta and P. K. Sett, 'Industrial Relations Law, Employment Security and Collective Bargaining in India: Myths, Realities and Hopes' (2000) 31 Industrial Relations Journal 144. 
B. Harriss-White and N. Gooptu, 'Mapping India's World of Unorganised Labour' (2001) 37 Socialist Register 89.

R. Hasan, D. Mitra and K. V. Ramaswamy, 'Trade Reforms, Labor Regulations, and LaborDemand Elasticities: Empirical Evidence from India' (2007) 89 Review of Economics and Statistics 466.

E. Hill, 'The Indian Industrial Relations System: Struggling to Address the Dynamics of a Globalizing Economy’ (2009) 51 Journal of Industrial Relations 395.

R. Jenkins, 'Labor Policy and the Second Generation of Economic Reform in India' (2004) 3 India Review 333.

P. Jha and S. Golder, 'Labour Market Regulation and Economic Performance: A Critical Review of Arguments and Some Plausible Lessons for India', Economic and Labour Market Papers No. 2008/1, Employment Analysis and Research Unit, Economic and Labour Market Analysis Department, International Labour Office, Geneva, 2008.

C.K. Johri, 'Industrialism and Industrial Relations in India: The Task Ahead' (1990) 25 Indian Journal of Industrial Relations 230.

C. K. Johri, 'Industrial Relations as Regulated by Law: Suggestions for Change' (1996) 31 Indian Journal of Industrial Relations 439.

C.K. Johri and S.M. Pandey, 'Employment Relationship in the Building Industry' (1969) 4 Indian Journal of Industrial Relations 433.

S. E. Kauff, 'Compulsory Disclosure of Hazards, Emergency Planning, and Training in the Workplace: India's Factories Act and the United States' Hazard Communication Standard' (1996) 17 Comparative Labor Law Journal 565.

V. D. Kennedy, 'The Sources and Evolution of Indian Labour Relations Policy' (1965) 1 Indian Journal of Industrial Relations 15.

A. U. Khan, 'Labour Market Rigidities in India' (2009) 1 Review of Market Integration 339.

D. Kooiman, 'Labour Legislation and Working Class Movement: Case of Bombay Labour Office, 1934-37' (1981) 16 Economic and Political Weekly 1807.

A. Kotwal, B. Ramaswami and W. Wadhwa, 'Economic Liberalization and Indian Economic Growth: What's the Evidence?' (2011) 49 Journal of Economic Literature 1152.

S. Kuruvilla, 'Linkages Between Industrialization Strategies and Industrial Relations/Human Resource Policies: Singapore, Malaysia, The Philippines and India' (1998) 49 Industrial and Labor Relations Review 635.

S. Lee and D. McCann (with A. Choi), 'The Impact of Labour Regulations: Measuring the Effectiveness of Legal Norms in a Developing Country', paper prepared for the conference Regulating for Decent Work, International Labour Office, Geneva, 2009. 
K. Mathur, 'Bonus Legislation in India' (1966) 1 Indian Journal of Industrial Relations 457.

V. K. R. Menon, 'The Influence of International Labour Conventions on Indian Labour Legislation' (1956) 73 International Labour Review 551.

R. Mitchell, P. Gahan, A. Stewart, S. Cooney and S. Marshall, 'The Evolution of Labour Law in Australia: Measuring the Change' (2010) 23 Australian Journal of Labour Law 61.

M. D. Morris, 'Labor Discipline, Trade Unions, and the State in India' (1955) 63 Journal of Political Economy 293.

M. D. Morris, 'Caste and the Evolution of the Industrial Workforce in India' (1960) 104 Proceedings of the American Philosophical Society 124.

F. C. Munson and A.C. Nanda, 'The Influence of Legal Framework on Labour Leaders and Their Unions' (1966) 2 Indian Journal of Industrial Relations 3.

R. Nagaraj, 'Employment and Wages in Manufacturing Industries: Trends, Hypotheses and Evidence’ (1994) 29 Economic and Political Weekly 177.

S. Nath, 'Developing New Perspectives on Industrial Relations: Role of Government' (1995) 31 Indian Journal of Industrial Relations 178.

C. Navin, 'Legal Regulations of Labour Market' (1999) 42 Indian Journal of Labour Economics 855.

T. S. Papola, 'Globalisation, Employment and Social Protection: Emerging Perspectives for the Indian Workers' (2004) 47 Indian Journal of Labour Economics 541.

T. S. Papola and J. Pais, 'Debate on Labour Market Reforms in India: A Case of Misplaced Focus’ (2007) 50 Indian Journal of Labour Economics 183.

C. Penfold, 'Off-Shored Services Workers: Labour Law and Practice in India' (2009) 19 Economic and Labour Relations Review 91.

M. Rajadhyaksha, 'Mergers and Amalgamations in India: Protecting Labour in Times of Change' (2007) 23 International Journal of Comparative Labour Law and Industrial Relations 375.

E. A. Ramaswamy, 'Trade Unionism and Caste in South India' (1976) 10 Modern Asian Studies 361.

E. A. Ramaswamy, 'Indian Management Dilemma: Economic Versus Political Unions' (1983) 23 Asian Survey 976.

E. M. Rao, 'The Rise and Fall of Indian Trade Unions: A Legislative and Judicial Perspective' (2007) 42 Indian Journal of Industrial Relations 678.

B. P. Rath and B. B. Das, 'Right to Strike: An Analysis' (2005) 41 Indian Journal of Industrial Relations 248. 
C. S. V. Ratnam, 'Impact of New Economic Policy on the Role of Trade Unions' (1993) 29 Indian Journal of Industrial Relations 55.

S. D. Roy, 'Employment Dynamics in Indian Industry: Adjustment Lags and the Impact of Job Security Regulations' (2004) 73 Journal of Development Economics 233.

A. de Ruyter, A. Singh, T. Warnecke and A. Zammit, 'Core v. Non-Core Standards, Gender and Developing Countries: A Review with Recommendations for Policy and Practice,' International Labour Office Conference on Decent Work, Geneva, 2009.

D. Saha, 'Conditions of 'Decent Working Life' of Street Vendors in Mumbai', paper prepared for the conference Regulating for Decent Work, International Labour Office, Geneva, 2009.

D. S. Saini, 'Compulsory Adjudication of Industrial Disputes: Juridification of Industrial Relations' (1991) 27 Indian Journal of Industrial Relations 1.

D. S. Saini, 'Reference Power of State in Industrial Dispute Adjudication: A Study with Reference to Industrial Disputes in Faridabad' (1993) 35 Journal of the Indian Law Institute 233.

D. S. Saini, 'Dynamics of New Industrial Relations and Postulates of Industrial Justice' (2003) 46 Indian Journal of Labour Economics 651

D. S. Saini, 'The Contract Labour Act: Issues and Concerns' (2010) 46 Indian Journal of Industrial Relations 32.

W.N. Salve. 'Labour Rights and Labour Standards for Migrant Labour in India', paper prepared for the conference Regulating for Decent Work, International Labour Office, Geneva, 2009

H. S. Sandhu and M. K. Sharma, " "Decent Work" and Labour Regulatory Mechanism: A Study of the State of Punjab (India)', paper prepared for the conference Regulating for a Fair Recovery Network, International Labour Office, Geneva, 6-8 July 2011.

P. Sarkar, 'Indian Labour Regulation and its Impact on Unemployment: A Leximetric Study, 1970-2006', Economics Department, Jadavpur University, Kolkata, 2011.

B. R. Sharma, 'Managerial Employees and Labour Legislation (1992) 28 Indian Journal of Industrial Relations 1.

A. N. Sharma, 'Flexibility, Employment and Labour Market Reforms in India' (2006) 41 Economic and Political Weekly 2078.

B. Singh, 'Global Crisis and Response of Labour Unity to Enforce Decent Working Conditions', Paper prepared for the conference Regulating for a Fair Recovery, International Labour Office, Geneva, 2011. 
M. Singh, 'Unorganised Industries: Conditions of Work and Labour Laws' (1988) 23 Indian Journal of Industrial Relations 373.

A. Sinha and R. Kanbur, 'Does Non-Compliance Lead to Informalisation: A State-Wise Analysis for India,' paper prepared for the conference Regulating for a Fair Recovery Network, International Labour Office, Geneva, 2011.

J. S. Sodhi, 'New Economic Policies and their Impact on Industrial Relations' (1993) 29 Indian Journal of Industrial Relations 31.

K. R. Shyam Sundar, 'State in Industrial Relations System in India: From Corporatist to Neoliberal?’ (2005) 48 Indian Journal of Labour Economics 917.

K. R. Shyam Sundar, 'Emerging Trends in Employment Relations in India' (2010) 45 Indian Journal of Industrial Relations 485.

B. P. Urla and D. Mitra, 'Indian Manufacturing: A Slow Sector in a Rapidly Growing Economy’, World Bank Policy Research Working Paper No. 4233, World Bank, 2007.

M. K. Varma, 'Role of Legislation in Regulating Labour-Management Relations in India' (1957) 8 Labor Law Journal 257.

S. Visweswaiajah, 'Discretionary Referrals: Compulsory Adjudication and the Industrial Disputes Act 1947' (1990) 32 Journal of the Indian Law Institute 1.

T. Warnecke and A. de Ruyter, 'A Race to the Bottom? Variations Between NIC States and Provinces in the Enforcement of Decent Work: A Comparative Study of Indonesia and India'. Paper prepared for the conference Regulating for a Fair Recovery Network, International Labour Office, Geneva, 6-8 July 2011. 